\title{
Seismic geomorphology and origin of diagenetic geobodies in the Upper Cretaceous Chalk of the North Sea Basin (Danish Central Graben)
}

Smit, F. W. H.; van Buchem, F.S.P.; Holst, J.H.; Lüthje, M.; Anderskouv, K.; Thibault, N.; Buijs, G.J.A.; Welch, M.; Stemmerik, L.

\section{Published in:}

Basin Research

Link to article, DOI:

$10.1111 /$ bre. 12285

Publication date:

2018

Document Version

Peer reviewed version

Link back to DTU Orbit

Citation $(A P A)$ :

Smit, F. W. H., van Buchem, F. S. P., Holst, J. H., Lüthje, M., Anderskouv, K., Thibault, N., Buijs, G. J. A., Welch, M., \& Stemmerik, L. (2018). Seismic geomorphology and origin of diagenetic geobodies in the Upper Cretaceous Chalk of the North Sea Basin (Danish Central Graben). Basin Research, 30(5), 895-925. https://doi.org/10.1111/bre.12285

\section{General rights}

Copyright and moral rights for the publications made accessible in the public portal are retained by the authors and/or other copyright owners and it is a condition of accessing publications that users recognise and abide by the legal requirements associated with these rights.

- Users may download and print one copy of any publication from the public portal for the purpose of private study or research.

- You may not further distribute the material or use it for any profit-making activity or commercial gain

- You may freely distribute the URL identifying the publication in the public portal 
MR. FLORIAN W.H. SMIT (Orcid ID : 0000-0001-8438-386X)

Article type : Original Article

\title{
Seismic geomorphology and origin of diagenetic geobodies in the Upper Cretaceous Chalk of the North Sea Basin (Danish Central Graben)
}

\author{
F.W.H. Smit ${ }^{1 *}$, F.S.P. van Buchem ${ }^{2 * *}$, J.H. Holst ${ }^{1}$, M. Lüthje ${ }^{1}$, K. Anderskouv ${ }^{3}$, \\ N. Thibault ${ }^{3}$, G.J.A. Buijs ${ }^{2}$, M. Welch ${ }^{1}$, L. Stemmerik ${ }^{4}$ \\ ${ }^{1}$ Technical University of Denmark, Danish Hydrocarbon Research and Technology Centre, Elektrovej \\ Building 375, 2800 Kongens Lyngby \\ ${ }^{2}$ Maersk Oil and Gas, Esplanaden 50, 1263 København K. \\ ${ }^{3}$ University of Copenhagen, Department of Geoscience and Natural Resource Management, $\varnothing$ ster \\ Voldgade 10, 1350 København K \\ ${ }^{4}$ University of Copenhagen, Natural History Museum of Denmark, Øster Voldgade 5-7, 1350 \\ Copenhagen $\mathrm{K}$ \\ *Corresponding author: fsmit@dtu.dk \\ ${ }^{* *}$ Now at Halliburton-Landmark, 97 Jubilee Avenue, Milton Park, Abingdon, OX14 4RW, UK.
}

December $17^{\text {th }} 2017$

8550 words (excluding references (2100), figure captions (2700)

Submitted first to Basin Research Q1 2017

Maersk Oil and Gas / DUC approval received 25/01/2017

This article has been accepted for publication and undergone full peer review but has not been through the copyediting, typesetting, pagination and proofreading process, which may lead to differences between this version and the Version of Record. Please cite this article as doi: 10.1111/bre.12285

This article is protected by copyright. All rights reserved. 


\section{Abstract (A)}

Kilometre-scale geobodies of diagenetic origin have been documented for the first time in a highresolution 3D seismic survey of the Upper Cretaceous chalks of the Danish Central Graben, North Sea Basin. Based on detailed geochemical, petrographic and petrophysical analyses it is demonstrated that the geobodies are of an open-system diagenetic origin caused by ascending basin fluids guided by faults and stratigraphic heterogeneities. Increased amounts of porosity-occluding cementation, contact cement and/or high-density/-velocity minerals caused an impedance contrast that can be mapped in seismic data, and represent a hitherto unrecognized, third type of heterogeneity in the chalk deposits in addition to the well-known sedimentological and structural features. The distribution of the diagenetic geobodies is controlled by porosity/permeability contrasts of stratigraphic origin, such as hardgrounds associated with formation tops, and the feeder fault systems. One of these, the Top Campanian Unconformity at the top of the Gorm Formation, is particularly effective, and created a basin-wide barrier separating low-porosity chalk below from high-porosity chalk above (a regional porosity marker, RPM). It is in particular in this upper highporosity unit (Tor and Ekofisk formations) that the diagenetic geobodies occur, delineated by 'Stratigraphy Cross-cutting Reflectors' (SCRs) of which 8 different types have been distinguished. The geobodies have been interpreted as the result of: 1) escaping pore-fluids due to top seal failure, followed by local mechanical compaction of high-porous chalks, paired with 2) ascension of basinal diagenetic fluids along fault systems that locally triggered cementation of calcite and dolomite within the chalk, causing increased contact cements and/or reducing porosity. The migration pathway of the fluids is marked by the SCRs, which are the outlines of high-density bodies of chalk nested in highly porous chalks. This study thus provides new insights into the 3D relationship between fault systems, fluid migration and diagenesis in chalks, and has important applications for basin modeling and reservoir characterization.

\section{Keywords}

Stratigraphy cross-cutting reflectors, cementation front, fluid migration, seal failure, pore collapse, compaction, ruptured pressure compartments

\section{Introduction (A)}

Heterogeneities controlled by initial depositional facies, post-depositional deformation, and diagenetic overprinting greatly influence recovery factor and production rates of oil and gas-bearing limestones. Yet, they are notoriously difficult to predict from seismic data and require integration with other data sets and disciplines. Seismic geomorphology has helped during the last decade to better understand large-scale depositional systems, notably in the deep marine siliciclastic environment (e.g. Posamentier et al., 2007). More recently, seismic data has also been instrumental in developing a more dynamic depositional paradigm with large moats and drifts formed by contourite currents, and large-scale slope remobilization features, in the extensive pelagic Upper Cretaceous chalk deposits of NW Europe (Lykke-Andersen \& Surlyk, 2004; Esmerode et al., 2008; Gennaro \& Wonham, 2014; Van der Molen, 2004).

This article is protected by copyright. All rights reserved. 
The chalk deposits are a mud-grade biogenic sediment, with very low permeability and fairly high porosity (Surlyk et al., 2003), and host the most important hydrocarbon reservoirs in the Danish part of the North Sea (Megson, 1992; Vejbæk et al., 2005) and a significant part of the hydrocarbons in the Norwegian sector (Brewster \& Dangerfield, 1984; D'Heure, 1984). It is a fairly homogenous sedimentary rock, composed mainly of remnants of eukaryotic phytoplankton (coccolithophorids) (e.g. Hancock, 1975; Scholle \& Halley, 1985; Fabricius, 2007), though some chalks in the Norwegian section of the North Sea can be rather argillaceous or cherty (e.g. Gennaro et al., 2013). The acoustic impedance (density multiplied by velocity) in chalk is dependent on three main parameters: porosity and pore-fluid, matrix mineralogy, and amount of contact cement (El Husseiny \& Vanorio, 2015; Fabricius, 2003; Gommesen et al., 2007; Regnet et al., 2015). Because of its general purity in the Danish Central Graben (90-100\% $\mathrm{CaCO}_{3}$ ), and well-constraint fluid content, seismic reflections in the chalk are often interpreted as porosity variations, which can be quantified through (deterministic) seismic inversion (Japsen et al., 2005; Cherret et al., 2011). However, it is possible that other minerals than calcite occur within the chalk, which could potentially offset the porosity estimation from such seismic inversion. Also, contact cement can increase the velocity without increasing the density of the rock significantly, and therefore cause a seismic signal (Fabricius, 2003). Geochemical and petrographical analyses from wells can potentially provide some insights into these effects.

Here we present a case study of seismic-scale heterogeneities within the Chalk Group in the Danish North Sea which we believe to be diagenetic in origin (Fig. 1 for location). We apply a seismic geomorphological workflow, which provides insights into the 3D architecture of large-scale heterogeneities and also serves as a spatial framework for combining other datasets at different scales (seismic to nanoscale) and from different disciplines (geophysics, geology and geochemistry). We combine methods that have previously been used to investigate diagenetic induced heterogeneity at outcrop- (e.g. Iran, Sharp et al., 2010, southern Spain, Martín-Martín et al., 2015), core and plug- (e.g. Scholle \& Halley, 1985; Fabricius, 2007), and micro-scale (e.g. Faÿ-Gomord et al., 2016) to characterize these heterogeneities further, and thereby better predict properties in undrilled areas. Improving ability to predict reservoir properties away from wells is indeed important for exploration (reservoir quality) and production purposes (understanding sweep-efficiency).

First, the stratigraphic units from Triassic to seafloor have been mapped using advanced seismic interpretation to provide the broad 3D geological model (stratigraphic units and fault fabric). Secondly, seismic attributes (e.g. spectral decomposition) have been displayed upon stratigraphic horizons below and within the chalk, to further highlight seismic heterogeneities, and reveal possible relationships with the underlying fault fabric (c.f. Smit et al., 2017). Finally, by closely matching petrophysical, petrographical, and geochemical information from two wells located within the heterogeneities we are able to associate the heterogeneities with extra-formational fluids.

This article is protected by copyright. All rights reserved. 
A likely candidate for introduction of these external fluids is the underlying fault systems that offset a thick succession of Mesozoic rocks. Therefore, this study not only demonstrates a combination of seismic geomorphology and well data, it also provides 1 ) new insights in the 3D relationship between fault systems, fluid migration, and diagenesis in limestones in general based on seismic data; 2 ) an alternative to published interpretations of similar features elsewhere in the North Sea Basin.

\section{Geological setting (A)}

The Danish Central Graben forms the southernmost branch of the North Sea Central Graben (Fig. 1). It comprises a complex set of half-grabens bounded to the south and east by the Ringkøbing-Fyn High, and to the west by the Mid North Sea High. The half-grabens formed during two major tectonic rifting phases (Japsen et al., 2003; Fig. 2 for an overview of lithostratigraphic units and major tectonic events). During the Permo-Triassic, an $\mathrm{E}-\mathrm{W}$ oriented stress regime led to $\mathrm{N}-\mathrm{S}$ oriented halfgrabens (Glennie et al., 2003; Goldsmith et al., 2003), whereas Late Jurassic rifting occurred in a NESW oriented stress regime, leading to generally NW-SE oriented half-grabens (Fraser et al., 2002). Substantial creation of accommodation space combined with high sedimentation rates led to deposition of thick Mesozoic siliciclastic successions (up to $4 \mathrm{~km}$ thick) below the Chalk Group.

Extensional faulting and rapid sediment loading led to multiple phases of Permian salt remobilization, thereby influencing semi-regional sedimentation patterns due to formation of diapirs and salt pillows (Michelsen et al., 2003; Karlo et al., 2014). Additionally, salt movements initiated large radial fault systems that remained active throughout Mesozoic and Cenozoic times (e.g. Harding \& Huuse, 2015).

The Upper Jurassic syn-rift succession is separated from the post-rift succession by the Base Cretaceous Unconformity (BCU), a basin-wide diachronous surface that is polygenetic in nature (Kyrkjebø et al., 2004). Thermal subsidence prevailed throughout most of the Cretaceous, but was interrupted by a distinct compressional phase that reached its climax during the early Campanian inversion. This resulted in major rearrangement of depocenters (Cartwright, 1989; Vejbæk \& Andersen, 2002; van Buchem et al., 2018) and sediment remobilization along newly formed highs (e.g. Back et al., 2011; Smit, 2014; van Buchem et al., 2018; Figs 17, 18 therein).

Palaeocene inversion movements likely resulted from intra-plate compressional stresses related to the Alpine collision and possibly ridge-push forces (Vejbæk \& Andersen, 2002), and could have reactivated fault systems present underneath the chalk rock. Rapid sediment loading, differential compaction of the Mesozoic sediments and halokinesis continued to play an important role for fault reactivation during the Cenozoic, and glacial loading and unloading during the Quaternary may have impacted the stability of the salt structures and associated fault systems (Rasmussen, 2013; Harding \& Huuse, 2015).

This article is protected by copyright. All rights reserved. 
Until recently, the official stratigraphic nomenclature for the chalk in the Danish North Sea was a subdivision into informal 'units' (e.g. Lieberkind et al., 1983), but a more pragmatic subdivision borrowed from the Norwegian and UK sectors was commonly used (e.g. Surlyk et al., 2003). Van Buchem et al. (2018) proposed the first formal lithostratigraphic subdivision for the Chalk Group in the Danish Central Graben (Fig. 2). Formations are based on a combination of seismic markers (CK1/7), biostratigraphy, and log markers (see Appendix in Van Buchem et al., 2018). The Early Campanian Unconformity (ECU), reflects a shift in basin morphology due to inversion tectonics, and separates the lower Hidra and Kraka formations (pre-inversion succession) from the upper Gorm, Tor and Ekofisk formations (syn- and post-inversion successions).

\section{Data and methods (A)}

Seismic (inversion) data and interpretation methods (B)

Seismic data (C)

A $2000 \mathrm{~km}^{2}$ subcrop of a recently re-processed regional seismic data set (pre-stack depth migrated) was available (Fig. 1). The quality of the data is in general very good, though it deteriorates around salt diapirs. The polarity follows North Sea convention, with a downward increase in acoustic impedance represented by a trough (shown in red). The dominant frequency in the Chalk Group is approximately $30 \mathrm{~Hz}$, and average acoustic velocity is around $3400 \mathrm{~m} / \mathrm{s}$, leading to an average vertical resolution of $28.3 \mathrm{~m}$ as a quarter of the wavelength of the dominant frequency (Sheriff, 1980).

\section{Seismic inversion porosity}

Seismic inversion porosity data is available over most of the study area. It was obtained from a deterministic inversion workflow (c.f. Cherret et al., 2011), using the Sine-1X and Olga-1X wells (Fig. 1) to derive the empirical relationships between seismic interval velocity from seismic data, and corresponding P-impedance and porosity from well data (Wagner, 2014). Standard deviation of the porosity was estimated from a detrended cross-plot of porosity over $\operatorname{Ln}(\mathrm{Ip})$, and amounts to 0.2 $\operatorname{In}(\mathrm{Ip})$ or $20 \% \mathrm{Ip}$, which corresponds to 10 porosity units. Importantly, the Olga-1X and Sine-1X wells did not penetrate the high Al chalks that are the focus of this study, and therefore factors other than porosity are ignored (e.g. possible heavier minerals and occurrence of near porosity-neutral contact cement), and could form a source of error. If significant amounts of minerals other than calcite (density $2.71 \mathrm{~g} / \mathrm{cm}^{3}$ ) occur within the rock, such as chert (2.3\% lighter), dolomite (7\% heavier), or sulfates ( $\mathrm{XSO}_{4} \cdot \mathrm{XH}_{2} \mathrm{O}, 11 \%$ heavier), the inversion based porosity can be inaccurate. To evaluate such factors, mineralogical and petrographical analyses throughout the stratigraphy are important.

Seismic interpretation methods and post-processing techniques

A neural network methodology has been applied for seismic interpretation (PaleoScan ${ }^{\mathrm{TM}}$, c.f. Pauget et al., 2009) in order to create, in a time-efficient manner, the large number of stratigraphy consistent horizon slices needed to investigate the limestone heterogeneities in detail. To increase

This article is protected by copyright. All rights reserved. 
the information extracted from the stratal horizons, spectral decomposition data revealed information in the frequency domain. Based on a dominant frequency of $30 \mathrm{~Hz}$, three spectral frequency cubes $(20,30,40 \mathrm{~Hz})$ were calculated using a matching pursue algorithm in GeoTeric 2016.2 (c.f. Morozov et al., 2013). Similar in aim but different in workings, seismic image processing was used to reveal high-resolution structural information using the eXchroma ${ }^{\mathrm{SG}}$ plugin for Petrel (c.f. Laake, 2013). Vertical linear features (which can represent faults or fracture swarms) are emphasized through 'swarm intelligence' of artificial ants (c.f. Pedersen et al., 2003). Petrel E\&P 2016 software (Schlumberger) has been applied to bring together data in a 3D visualization environment.

Wireline logs (B)

Well O-1X only has gamma ray and deep resistivity logs, whereas Sine-1X has a full log suite, including sonic velocity, density and neutron-porosity, so Sine-1X was used for the seismic-well tie. In order to compute porosity in O-1X, the deep resistivity log of O-1X can be used in conjunction with core porosity data and Archie's Law (Archie, 1942). With known average porosity (0.253), water saturation (1) and deep resistivity $(0.5236 \Omega . \mathrm{m}$, true resistivity), a mud resistivity of $0.0335 \Omega . \mathrm{m}$ is calculated, in line with the brine saturated system during logging (final well report). Now the porosity can be re-written as a function of resistivity, water saturation (assuming no hydrocarbons), and previous calculated mud resistivity:

$$
S_{w}=\sqrt{\frac{1}{\Phi^{2}} * \frac{R_{w}}{R_{t}}}, \text { becomes } \Phi=\sqrt{\frac{0.0335}{R_{t}}}
$$

Drill cutting analyses (B)

More direct characterization from the rocks was obtained using a $10 \mathrm{~m}$ core from $0-1 \mathrm{X}$ and drill cuttings ( $9 \mathrm{~m}$ intervals for $\mathrm{O}-1 \mathrm{X}$ and $3 \mathrm{~m}$ intervals for Sine-1X). For petrographical characterization, rock chips and 12 thin-sections were investigated under SEM. Nomenclature of Fä̈-Gomord et al. (2016) is loosely followed to classify the diagenetic overprint of the samples. From each well, 50 nannofossil slides were prepared and analyzed quantitatively (c.f. Thibault \& Gardin, 2006) in order to establish a time framework, following the subdivision of Fritsen et al. (1999) modified by Boussaha et al. (2016). Sample spacing is $9 \mathrm{~m}$ in 0-1X and $18 \mathrm{~m}$ Sine-1X, with closer spacing around the RPM $(3 \mathrm{~m})$.

Geochemical analyses include carbon, oxygen, and sulphur isotope geochemistry, and X-Ray Fluorescence (XRF). A deviation of the oxygen isotope ratio $\left(\delta^{18} O\right)$ from Cretaceous seawater can indicate a certain degree of diagenesis, as with increasing temperature lighter oxygen isotopes will be taken up into the crystal lattice, although bulk values also depend on the fluid from which the cement precipitated (Craig, 1957). Carbon and oxygen isotopes were analysed at Iso-Analytical (UK) using continuous flow isotope ratio mass spectrometry (CF-IRMS), and values are reported as $\delta^{13} \mathrm{C}$ and $\delta^{18} \mathrm{O}$, deviations in parts per thousand relative to the V-PDB and V-SMOW standard. Analyses

This article is protected by copyright. All rights reserved. 
were performed on every drill cutting sample from the entire Chalk Group, giving a resolution of $9 \mathrm{~m}$ $(0-1 X)$ and $3 \mathrm{~m}$ (Sine-1X). Standard deviations are reported to be better than $0.08 \%$ for $\delta^{13} \mathrm{C}$ and $0.02 \%$ for $\delta^{18} \mathrm{O}$. Sulphur isotope ratios in anhydrite from $\mathrm{O}-1 \mathrm{X}$ were obtained at Isotope Tracer Technologies Inc. (Canada), and reported as $\delta^{34} S$ showing deviation in parts per thousand relative to the Vienna-Canyon Diablo Troilite (VCDT) standard. Standard deviation from repeated samples is reported to be $0.2 \%$.

Certain chemical components can be used to describe the type of diagenesis, such as $\mathrm{Mn}$ and $\mathrm{Sr}$ (open or closed-system c.f. Banner \& Hansen, 1990), Mg (dolomitisation), and Si/Al (for the presence of silica phases). To characterize this throughout the stratigraphy, XRF analyses were carried out at ALS Minerals (Ireland) of drill cutting material with a vertical spacing of $9 \mathrm{~m}$ in 0-1X, $6 \mathrm{~m}$ for the upper $305 \mathrm{~m}$ of Sine-1X and $46 \mathrm{~m}$ for the remaining of the Chalk Group. Accuracy is reported to be within the limits of the reference samples.

\section{Results (A)}

Unconformities at the crest of the Ryan structure (B)

A seismic section between wells $0-1 X$ and Sine- $1 X$ shows the different positions of the two wells within the basin: O-1X on top of the Ryan Anticline, Sine-1X on the Rinkøbing-Fyn High (Fig. 3a). Biostratigraphic data from well O-1X show that the lowermost chalks between CK-1 to 3 ( 65 m thick) are highly condensed, of Santonian - earliest Campanian age, and overlie Barremian shales (Lower Cretaceous), thus reflecting a major hiatus (maximum of $45 \mathrm{Myr}$ ). Onlapping onto the Ryan structure is observed within the thin CK-1 to CK-3 strata in the seismic section and truncation is observed at the CK-3 marker (Fig. 3a, black arrows, ' $T$ '). In Sine-1X, a thin package of Albian shales (Lower Cretaceous) overlies the Precambrian basement rocks. The oldest chalks are of Coniacian Santonian age ( $160 \mathrm{~m}$ thick), and are separated from the shales by a major hiatus.

Onlapping onto the CK-3 marker occurs at the transition from the eastern basement high to the Mesozoic basin (i.e. where the Coffee Soil Fault offsets the lowermost chalk; Fig. 3a, white arrows) and onto the Ryan Anticline, as well as truncated reflectors (Fig. 3a, 'T's and black arrows). Biostratigraphic data from 0-1X show that the chalks between CK-3 to CK-5 are condensed ( $37 \mathrm{~m}$ thick) and of Early/Mid Campanian age, while the upper Campanian is missing (Fig. 4). A thicker and complete Campanian succession occurs at Sine-1X (240 m), and thus a correlative conformity is observed at Top Campanian (Fig. 4, 'C.C.'). The CK-3 marker reflects the separation of the preinversion basin (Cenomanian - Earliest Campanian, CK-1 to CK-3, Fig. 2) from the post-inversion basin (Early Campanian - Danian, CK-4 to CK-7, Fig. 2) (c.f. van Buchem et al., 2018). The seismic section and biostratigraphic data thus show that the CK-3 marker forms an unconformity due to tectonic inversion, and that sedimentation rates at the Ryan Anticline remained low during Campanian times, while at Sine-1X sedimentation was continuous.

This article is protected by copyright. All rights reserved. 
The seismic section shows strata on top of the CK-5 marker onlapping towards the Ryan Anticline (yellow arrows in Fig 3a), and the surface itself shows erosional truncation of underlying Campanian strata (T's and black arrows in Fig. 3a). The CK-5 marker forms a major hiatus within the biostratigraphy of O-1X (where the Upper Campanian missing), whereas in Sine-1X continuous sedimentation occurred creating onlapping onto the Ryan anticline (Figs 3a and 4). The biostratigraphy and seismic stratigraphy indicate that the Ryan Anticline remained a basinal high during latest Campanian to earliest Maastrichtian times with low sedimentation rates and erosion, and it became buried during the UC-16 S3 subzone (Figs 3a and 4).

The CK-5 marker is a high-amplitude and low-frequency trough reflecting significant increase in acoustic impedance at the interface (Fig. 3a, b). Both neutron-derived porosity and seismic inversion porosity data show that it divides the chalk regionally into an upper high-porosity unit with $20-40 \%$ porosity, and a lower low-porosity unit with overall porosity between $0-10 \%$ and some thinner intervals with up to $20 \%$ porosity (Figs $3 \mathrm{~b}$ and 4 ). We therefore suggest using the more informative name 'Regional Porosity Marker' (RPM) for the CK-5 surface. The neutron-derived porosity log in Sine-1X shows a stepwise downward transition from high to low porosity within a $20 \mathrm{~m}$ interval corresponding to the RPM (Fig. 5). In O-1X, modelled porosities show slightly higher values below the RPM, between 8-20\%, though the GR-calculated shale volumes might mean that the modelled (resistivity) porosity underestimates true porosity (Figs $3 \mathrm{~b}$ and 4 ).

Petrography and geochemistry (C)

The chalk beneath the RPM is generally well-cemented. Nano- and microfossils (fragments) are recrystallized with large overgrowths, and grain-to-grain contacts have coalesced (Figs 6a, b and 7a, b). The main differences between the two wells are the large amounts of crystalline dolomite in $\mathrm{O}$ 1X (Fig. 6b) and the presence of stylolites in Sine-1X (Fig. 7b). The dolomite crystals are 10-100 micron in size, replacing a large amount of the chalk. In contrast, the chalk above the RPM is less cemented with better preservation of coccolith material, less calcite overgrowth, and less contact cement (Figs $6 c$ and 7c, Zone 2). It shows generally good preservation of porosity, and limited amounts of larger dolomite crystals (Figs $6 \mathrm{~d}$ and $7 \mathrm{~d}$ ).

The chalk below the RPM shows a bulk shift towards more negative $\delta^{18} O$ values, from $-3.5 \%$ $(\phi=25 \%)$ to $-6 \%$ o $(\phi=1.5 \%)$ in Sine-1X (Fig. 5a), though some intervals have slightly more positive values (e.g. $2525-2650 \mathrm{~m}$ ). The shift is less dramatic in $0-1 \mathrm{X}$, from -2.9\%o ( $\phi=22 \%$ ) to $3.7 \%$ ( $\phi=7 \%$ ), and values increase again towards the base of the chalk (Figs 4 and 5 ). The neutron-porosity correlates positively with the $\delta^{18} \mathrm{O}$ : with decreasing porosity, the $\delta^{18} \mathrm{O}$ values also become more negative (Fig. 5b). Cross-plotting $\delta^{13} C$ and $\delta^{18} O$ values, shows a clear distinction between the low-porosity chalk below the RPM with high $\delta^{13} C$ and low $\delta^{18} O$ values (yellow) and high-porosity chalk above the RPM characterized by high $\delta^{13} C$ and high $\delta^{18} O$ values (green) (Fig. 8a). In O-1X, higher porous zones below RPM form outliers with higher $\delta^{18} O$ values.

This article is protected by copyright. All rights reserved. 
The $\mathrm{Mn} / \mathrm{Sr}$ ratio is highest at the base and top of the Chalk Group in both wells. The high-porosity chalk immediately above the RPM is characterized by the lowest overall $\mathrm{Mn} / \mathrm{Sr}$ ratios, and in both wells the $\mathrm{Mn} / \mathrm{Sr}$ ratio increases immediately beneath the RPM (Figs 4 and $8 \mathrm{~b}$ ). The Si/Al ratio shows rather low values below the RPM in Sine-1X, increasing rapidly towards the base of the Chalk Group, coinciding with higher $\mathrm{Mn} / \mathrm{Sr}$ ratios (Fig. 4, and see red dots in Fig. 8c). In O-1X, an increase in Si/Al is found at the RPM. The low Mn/Sr ratios in the high-porosity chalk (Zone 2) indicate that diagenesis likely occurred in a closed system (Banner \& Hanson, 1990) (Fig. 8b). The increased Mn/Sr ratios in chalk beneath the RPM, in both wells, suggests larger water:rock interaction and thus more opensystem diagenesis. The high $\mathrm{Mn} / \mathrm{Sr}$ ratios at the base of the Chalk Group suggest more open-system diagenesis has occurred here. The magnesium content of the chalk below the RPM is relatively high and fluctuates by a large amount in 0-1X (up to 8 weight percent, Fig. 4), which could partly reflect the presence of the dolomite. Within the Lower Cretaceous, and at the fault plane, increased amounts of sulphates occur with $\delta^{34} S$ values of 11-15\%, which is similar to Triassic/Permian anhydrites in the adjacent Nils-1 well (Fig. 1).

Stratigraphy Cross-cutting Reflectors (B)

2D architecture (C)

Several high-angle $\left(30-55^{\circ}\right)$ reflectors with anomalously high amplitudes cross-cut the seismic stratigraphic framework defined by van Buchem et al. (2018) (Fig. 9). They are accordingly named Stratigraphy Cross-cutting seismic Reflectors (SCRs).The SCRs are characterised by continuous to semi-continuous, low-frequency, high-amplitude peak reflectors (i.e. bounding lower Al rocks), which cut through the seismic stratigraphic horizons at variable angles ( $30-55^{\circ}$ relative to horizontal) (Fig. 9). The cross-cutting creates apparent erosional truncation of the reflectors outside the boundaries and apparent onlapping patterns within the SCRs. In many sections, these reflectors can be traced across and within the area of the SCRs (CK-5a in Fig. 9).

The SCRs architecture is characterized by: 1 ) an anomalously high-amplitude trough (i.e. bounding high Al rocks) at the top of the features at Top Chalk; 2$)$ steeply dipping $\left(30-55^{\circ}\right)$ conjugate and downward-converging anomalously high-amplitude peak reflectors (i.e. bounding rocks with lower Al), which create various shapes depending on transect orientation; 3) anomalously high-amplitude, high-frequency reflectors inside the V-shape; 4) a vertical anomalous high-amplitude peak/trough couplet at the base, 'cutting' through a continuous horizontal reflector (Fig. 9, Table 1). The height of the SCR-defined V-shapes is typically 20-200 ms two-way-time (TWT) (i.e. 34-340m, with a velocity of $3400 \mathrm{~m} / \mathrm{s}$ ). The lower part of the $V$-shape is $50 \mathrm{~m}$ wide, and it widens to $5 \mathrm{~km}$ in the upper part.

This article is protected by copyright. All rights reserved. 
Table 1 summarizes the observed types of SCR, which are illustrated with 2D and plan view images. Three main groups are distinguished: (a) simple U- or V-shapes (Types 1, 2), (b) single or double Wshapes (Types 3, 4), and (c) more diverse patterns (Types 5, 6, 7 and 8). The 2D-architecture is highly dependent on orientation of the seismic section relative to the main axis. The $\mathrm{U}$-shape is seen in sections sub-parallel to the main axis, the V-shape in sections perpendicular to a single feature, whereas the (double) W-shapes seem to be the result of merging of adjacent $\mathrm{V}$-shapes. Where faults offset the chalk, 'dashed' anomalies can be seen (Table 1, type 5) in combination with $V$ and (double) $\mathrm{W}$-shapes (Type 6). Subtle amplitude anomalies can indicate a distal position relative to the features (Type 7, see Fig. 3a at 0-1X location).

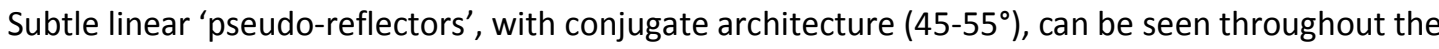
chalk (Fig. 10a and insets therein). These linear amplitude variations are emphasized on ant-tracked structural data from eXchroma ${ }^{\mathrm{SG}}$ (Fig. 10b). They correlate well with underlying fault fabric, and extend far into the Palaeocene-Eocene mudstones. They seem to be the precursor of the better developed V/W-shaped SCRs. The latter resemble gentle horst and graben structures, where the chalk inside the SCRs is analogous to the grabens and the chalk outside is analogous to the horsts. The topography is $10-50 \mathrm{~ms}$ TWT (i.e. $17-85 \mathrm{~m}$, with an average velocity of $3400 \mathrm{~m} / \mathrm{s}$ ).

Lateral architecture (C)

In map view, the SCRs are lobate to elliptic and typically have 'fingers' at one side of the lobe (Fig. $11 \mathrm{a}, \mathrm{b})$. The lobes/ellipses are typically 1-5 km long and 0.2-3 km wide, and occur: 1 ) at the crest of the Ryan Anticline, most clearly where the master normal fault is linking up with the NW-SE oriented fault (compare with Fig. 12a); 2) along the Coffee Soil Fault, where en-echelon faults can also be seen; 3 ) along radial faults of salt diapirs. The lobes are often surrounded by 'halos' with dimmer seismic expression, because of the lower seismic amplitude. Cross-cutting relationships between individual lobes/ellipses are common and at least four 'generations' can be distinguished, where the most recent lobes are the brightest (have the highest seismic amplitudes) (Fig. 11b). The merging of lobes leads to the $\mathrm{W}$-shapes in $2 \mathrm{D}$ section.

3D stratigraphic architecture (C)

Stratal slicing shows that the 3D stratigraphic architecture outlined by the SCRs follows a system of vertical conduits, which connect to the underlying fault system, coincide with the subtle linear features seen on 2D section, and spread laterally over time in a zig-zagging pattern (Fig. 12). At the deepest stratigraphic level (Fig. 12a, Intra-Jurassic), the Jurassic fault structures at the top of the Ryan crest are clearly seen as N-S striking lineations, corresponding to the normal faults seen in 2D section (Fig. 9). The Coffee Soil Fault is represented as a westward dipping fault plane, and the Upper Jurassic growth package can be seen on the seismic section in the back (Fig. 12a).

This article is protected by copyright. All rights reserved. 
The N-S striking normal faults can still be observed at the Base Cretaceous Unconformity (BCU) level (Fig. 12b), showing that they remained active until at least the Early Cretaceous. The crestal zone of the Ryan Anticline shows a dominance of blue colours, indicating a large contribution of high frequency wavelets to the seismic traces representing thin beds or sharp lithology changes (c.f. Partyka et al., 1999). It is also clear that the O-1X well penetrates a first order normal fault at 2335 $\mathrm{m}$, and cuttings from this interval contain a large amount of sulphates with typical Permian/Triassic sulphur isotope values between $11.4-15.1 \%$ (Fig. 13a).

The lower part of the Chalk Group immediately below the RPM (Fig. 12c) shows that there is a distinct high-frequency zone in the seismic signal in the area over the Ryan crest. This distinct zone diminishes 50 ms upwards and the spectral signal becomes more homogenous at the RPM. High magnesium contents (4-8 wt\%) and dolomite are common in this interval (Figs 5 and 13b).

The sharp NW-SE oriented lobate shapes above the RPM (Fig. 12d) correspond to the base of the Vshapes and (double) W-shapes. They are 50-500 m wide, and 1-3 km long, and occur between the O-1X and Sine- $1 \mathrm{X}$ wells.

Near the top of the Tor Formation, the anomaly outlined by the SCRs extends further laterally $(5 \mathrm{~km}$ by $10 \mathrm{~km}$ ) (Fig. 12e), corresponding to the widened $V$ shapes seen in cross-section, and the contribution of high-frequency wavelets is more dominant. It is also evident that $\mathrm{W}$ and $2 \mathrm{~W}$ shapes are the result of the merging of $\mathrm{V}$ shapes, as the rims of the individual $\mathrm{V}$ 's sometimes are still visible and correspond to the subtle conjugate lineations (see Fig. 10b). Along the Coffee Soil Fault, NE-SW en-echelon faults running oblique to the main $\mathrm{N}-\mathrm{S}$ faults are overprinted by the seismic anomaly (Figs $10 \mathrm{~b}$ and 12e). In addition, lobate shapes are observed along the radial faults of the diapirs.

At the Top Chalk surface (Fig. 12f), the anomaly covers the largest area ( $20 \mathrm{~km}$ by $45 \mathrm{~km}$ ) and occurs at: 1 ) the crest of the Ryan Anticline; 2 ) along the flanks of the Nils, Vagn and Tove salt diapirs and; 3 ) the Coffee Soil Fault. The outline is sharply defined, with a transition zone of only 20-30 m into unaffected low acoustic impedance chalk. Sine-1X penetrates the rocks characterized by this higher acoustic impedance signal (up to $6 \mathrm{x}$ background value).

Seismic inversion and petrophysics (C)

Seismic inversion data (Figs 3b, 10c, and Table 1) show that the chalk within the SCRs (Zone 3, Fig. 4) has $10-20 \%$ percentage points lower porosity than the chalk at the same stratigraphic level outside of the features. A sharp transition from $30 \%$ to less than $15 \%$ porosity occurs over less than $20-30 \mathrm{~m}$ laterally. The highest amplitudes are the brightest expressions in spectral decomposition attribute, and reflect the lowest porosity bodies (Fig. 11). The most recent generation of cross-cuts thus show the lowest porosity. This pattern continues upwards in the Ekofisk Formation where the areas with

This article is protected by copyright. All rights reserved. 
lower porosity widen up (Fig. 12f). Areas with the lowest porosity in the Tor Formation also correspond to the areas the lowest porosity in the Ekofisk Formation.

O-1X penetrates a rod-shaped seismic anomaly at $1925 \mathrm{~m}$ (Type 5), which persists upward and represents a (modelled) porosity reduction from $35 \%$ to $28 \%$ (Figs 13 and 5). Similarly, in Sine-1X at 1829-1872 m (Figs 4, 5), a reduction in neutron-derived porosity from $34 \%$ to $20 \%$ coincides with an increase in Al. The interval between the RPM and the SCRs (Zone 2) is characterized by chalk with porosity of $25-30 \%$.

The time isochore between the RPM (base SCRs, CK-5) and Top Chalk (Top SCRs, CK-7) is on average $150 \mathrm{~ms}$ TWT thick ( $255 \mathrm{~m}$, with average velocity $3400 \mathrm{~m} / \mathrm{s}$ ) within the SCRs and $220 \mathrm{~ms}$ TWT thick ( $330 \mathrm{~m}$, with average velocity $3000 \mathrm{~m} / \mathrm{s}$ ) outside the SCRs (Fig. 14, see Fig. 9 for markers). This is roughly equivalent to a $20 \%$ volume reduction inside the SCRs and gives rise to the horst and graben topography seen in 2D sections (Fig. 3a).

Petrography and geochemistry (C)

The 0-1X core (1873-1882 m, Fig. 4, Danian, $77 \%$ recovery) is potentially located within a SCR alteration (Fig. 3a, b). The chalk has $20-30 \%$ porosity (final well report) although it is fairly silicified, contains multiple 1-10 cm thick clay seams in the lower part (1873-1876 m, Fig. 4), cleans upward, and contains several 1-10 $\mathrm{cm}$ thick chert lenses. In addition, several $\mathrm{mm}$-wide and centimeter to decimeter long calcite veins, containing coarse-grained (mm-sized) translucent calcite crystals, are present (Fig. 13c). Unfortunately, no data are available from a fully developed SCR, so the data from O-1X are used to predict the properties of the rocks in the SCRs (e.g. the 'rod', Type 5 as seen in Fig. 13).

SEM data from the chalk in Zone 3 show large calcite overgrowths on the coccoliths, which fill the pore spaces and create coalescent grain-to-grain contacts. It also shows recrystallized nano- and micro-fossil (fragments), as well as 5-100 micron dolomite crystals. Large amounts of micron-sized quartz aggregates are also seen to cover the coccoliths ('Si' in Fig. 6e). Thin sections show higher degree of recrystallization of nano-fossils compared to Zone 2 , and dolomite cements are reflected by lighter, sharp edged crystals, 5-100 micron in size (' $D$ ' in Figs $6 e$, f; and 7e, f).

The $\delta^{18} O$ values of the chalk inside the SCRs (Zone 3 ) range from -6 to $-9 \%$, with the most negative values representing calcite-filled fractures and the immediately adjacent chalk (Fig. 4, 13c). Less porous intervals show more negative $\delta^{18} O$ values, suggesting a correlation between oxygen isotopes and porosity (Fig. 5b). It likely reflects that the pore-filling cement and dolomite, as observed in the SEM (e.g. Figs $6 e, f$, and 7e, f), have negative $\delta^{18} O$ values.

This article is protected by copyright. All rights reserved. 
The $\mathrm{Mn} / \mathrm{Sr}$ ratio of chalk within the SCRs is up to 1.10 in O-1X (11x baseline) and 26.6 in Sine-1X (13.3x baseline) (Fig. 4). Zone 3 chalk has on average the largest ratio of $\mathrm{Mn}$ relative to $\mathrm{Sr}$, and falls furthest along the water:rock interaction trend (Fig. 8b). A continuous increase in water:rock interaction can be interpreted from the $\mathrm{Mn} / \mathrm{Sr}$ ratios from Zone 2 (the least) to Zone 1 and Zone 3 (the most).

The magnesium content increases towards the top of the chalk in both O-1X and Sine-1X (Fig. 4). This could reflect the occurrence of dolomite crystals, as observed in SEM (Figs 6e,f and 7e,f).

$\mathrm{Si} /$ Al-ratios are much higher in Zone 3 in both wells (1844 $\mathrm{m}$ in Sine-1X and $1908 \mathrm{~m}$ in O-1X), possible due to presence of quartz aggregates as seen with SEM (Figs 4, 6e, f, and 7e, f). It seems to correlate with an increase in $\mathrm{Mn} / \mathrm{Sr}$ ratios (Fig. 4), which on cross-plots deviate from the clay trend at higher $\mathrm{Mn} / \mathrm{Sr}$ ratios (Fig. 8c).

Pre- and post-chalk observations (B)

The superposition of the SCRs and the underlying fault fabric points towards a correlation (Fig. 15). In the study area, thickness variations are influenced by the two rifting phases, a doming phase, and salt (re-) mobilization (Figs 2 and 16, T-1 to 3, and J-1 to 3 ).

The Ryan Anticline is cored by a $2.5 \mathrm{~km}$ thick Triassic growth wedge (T-1 to 3), reflecting the Triassic rifting phase. These deposits comprise continental sandstones, mudstones, and evaporites of the Triassic Keuper Group. Seismic packages with low signal/noise ratio, within the Triassic and LowerMiddle Jurassic sediments (J-1), may represent remobilized Triassic/Permian evaporites (' $P$ ' in Figs 9 and 16).

The Upper Jurassic (J2-3) is represented by a $1.5 \mathrm{~km}$ thick growth wedge along the N-S trending Coffee Soil Fault, where mainly marine mudstones accumulated. Over the crest of the Ryan Anticline the packages rapidly thin to $500 \mathrm{~m}$, indicating less accumulation space, which could have been the result of Mid-Jurassic doming (Michelsen et al., 2003).

The multiple tectonic events have generated a multi-oriented, complex fault fabric underneath the chalk (Fig. 17). The most pronounced orientations are: 1) N-S to NNE-SSW, reflecting Permo-Triassic extensional faults and the faults at the crest of the Ryan Anticline (e.g. Glennie et al., 2003; Goldsmith et al., 2003); 2) NW-SE, reflecting Late Jurassic extensional faults (Michelsen et al., 2003); and 3 ) radial faults around the salt diapirs. Where a higher intensity of faults is present underneath

This article is protected by copyright. All rights reserved. 
the chalk, more pronounced SCRs are observed. The overall NE-SW trending SCRs are at critical places offset towards a NW-SE orientation, which coincides with the occurrence of underlying Late Jurassic faults.

A seismic velocity geosection over the Ryan Anticline shows three major elements (Fig. 18): 1) low velocity clays on top of the chalk $(2000 \mathrm{~m} / \mathrm{s}) ; 2)$ the chalk, comprising a low velocity upper layer $(2800-3400 \mathrm{~m} / \mathrm{s})$ and a high velocity lower layer $(3400-5000 \mathrm{~m} / \mathrm{s})$, divided by the RPM; 3 ) low velocity Jurassic-Triassic strata, forming a 'wing' of low velocity just below the Chalk Group (2300$2600 \mathrm{~m} / \mathrm{s})$.

Anhydrite has been reported at three stratigraphic levels in 0-1X (Final Well Report 0-1X). The sulphates occur at $2335 \mathrm{~m}$, where the well penetrates the master fault, and in the overlying Lower Cretaceous and lowermost Chalk Group from 2240-2317 m (Fig. 13a). Sulphur isotope analysis of $\mathrm{mm}$-sized translucent sulphate crystals, forming up to $20 \%$ of the cuttings, gave $\delta^{34} S$ values of $11.4 \%$ (2289 m), 12.1\%o (2313 m), 14.1\%o (2316) and 11.8\%o (2320 m). For comparison, Triassic Keuper anhydrite in 0-1X has $\delta^{34} S$ values between 14.3-15.5\%, and in the Permian anhydrite in Nils-1 $\delta^{34} S$ ranges from 12.3-13.1\%o. Since samples were taken from unwashed material, it could reflect precipitation of salt from drill filtrate. However its occurrence specifically at the fault plane and in Zone 1, and the similar isotope signatures, suggest that it is natural.

A spectral decomposition slice at the top of the Våle Formation (post-chalk, Fig. 19) shows several discontinuities parallel to the Ryan Anticline, the Coffee Soil Fault, and the Nils diapir. They correspond in 2D sections to places where the Våle marker is slightly offset by underlying faults. It will be argued that this is where the main top seal of the chalk failed and overpressure could leak out of the system, forming the SCRs.

\section{Discussion (A)}

Chalk below the Regional Porosity Marker (RPM) (B)

Erosion and condensation forming early intra-chalk seals(C)

Esmerode et al. 2007 observed an erosional unconformity at the top of the Campanian in the Danish basin. They interpreted this surface as reflecting increased ocean bottom current activity that winnowed chalk from basinal highs and deposited it as drifts in other parts. Similar observations were made by van der Molen (2004), who recognized erosion and non-deposition of the CK-7 sequence (Upper Campanian). Gennaro (2011) also recognized increased erosion at the Top Magne reflector (top Campanian). This is in agreement with a global increase in ocean circulation as described by Jung et al. (2013). In the study area, a similar unconformity is observed at the top of the Campanian (i.e. the RPM), which is expressed as a hiatus at the Ryan Anticline (four subzones missing), while deposition continued at the more basinal Sine-1X location (Fig. 3a). During times of low sedimentation rates, early cementation can occur at some distance below the seafloor under

This article is protected by copyright. All rights reserved. 
the influence of organic degradation and internal bioclastic carbonate redistribution (Molenaar and Zijlstra, 1997). The long-term position of O-1X on a structural high resulted in condensation of most of the pre-Maastrichtian section. It is therefore possible that early diagenesis could explain the combination of low porosity and $\delta^{18} O$ values that are less negative than at Sine-1X (e.g. closer to Cretaceous seawater, Fig. 5b). Subsequent burial compaction might have further reduced the porosity to form a very dense chalk rock at the top of the Ryan structure, which served as an important intra-chalk barrier for later fluid migration. The slightly increased $\mathrm{Mn} / \mathrm{Sr}$ ratios immediately beneath the RPM in 0-1X indicate that little rock:water interaction was possible in this zone, and might reflect this sealing character. The higher $\mathrm{Mn} / \mathrm{Sr}$ ratios within the lowermost chalks could reflect stagnating basinal fluids beneath this intra-chalk seal. The more negative $\delta^{18} O$ values and higher $\mathrm{Mn} / \mathrm{Sr}$ ratios at Sine- $1 \mathrm{X}$ beneath the RPM could indicate less early cementation and more burial diagenetic cement.

The highly fluctuating Mg-content observed in O-1X below the RPM is likely to reflect the occurrence of dolomite, which is observed as 'aggressive' crystals under SEM (Figs 6 and 7). As the chalk is a relative low-Mg calcite, small amounts of dolomite could originate from recrystallization of high-Mg or aragonite bioclasts (Molenaar and Zijlstra, 1997). However, the large amounts of dolomite (with crystals up to 100 microns) suggest that it is more likely that the Mg was introduced by an extraformational fluid. This is supported by the occurrence of magnesium sulfates on the fault plane, in the Lower Cretaceous strata, and in the lowermost part of the chalk. Evaporites within the chalk are not common and only present where salt diapirs have pinched the formation. A similar origin is argued here, as the major fault is deeply rooted into the Triassic and Permian salt that forms the anticline (Figs 9 and 16). In addition, the sulphur isotopic values are comparable to those of the sulphate salts obtained from the Nils diapir, where most of the salt retreated to. The RPM thus represents the top of an early cemented/compacted zone in the chalk formed as a result of seafloor bathymetry and increased bottom currents. It formed an important intra-formational seal for later fluid migration. We argue that basinal fluids accumulated at the highest points underneath the chalk beneath the RPM (high Mn/Sr ratios), and ultimately found a way through the RPM into the overlying high porous chalks along fairways that evolved into the SCRs.

\section{Stratigraphy Cross-cutting Reflectors (SCR) (B)}

Diagenetic geobodies (C)

The SCRs outline irregular seismic-scale bodies of high-density chalk that dip steeply and cross-cut the stratigraphy (Fig. 3a, Table 1). Seismic inversion data suggest that the chalk within the SCRs is low-porosity chalk nested within high-porosity chalk (e.g. $15 \%$ porosity within the SCRs vs $30 \%$ outside). Without data from within these features, it is difficult to assess whether the increase in acoustic impedance is entirely controlled by porosity, or whether localized mineralogy (dolomite/sulphates) and/or contact cement contributed as well. The cored interval in 0-1X represents the closest proxy of the SCRs, as it falls within the seismic anomaly. In this core the chalk is heavily silicified, and larger amounts of contact cement are observed (compare Fig. $6 f$ with $d$ ). It also contains fractures that are filled with calcite characterized by the most negative $\delta^{18} O$ values,

This article is protected by copyright. All rights reserved. 
and surrounded by zones of chalk with pore-filling cement (which also has very negative $\delta^{18} O$ ). The low porosity, high amounts of contact cement, and possible dolomite, will give these rocks a high acoustic impedance compared to the high-porosity chalk within which they are nested, and will generate the peak reflector that outlines these geobodies (c.f. Fabricius, 2003).

At the SCRs, the later two-way travel time of top Chalk Group and the time isochore showing a volume reduction of $10-20 \%$, suggest that some mechanical compaction and/or dissolution must have occurred. Stylolites have not been observed in the core but dissolution cannot be ruled out, as no direct data is available from within the SCRs. Mechanical compaction can be quite dramatic in high-porosity chalks due to the large strain accumulated in such rocks (Fabricius, 2014). If some of the overpressured fluid could escape due to seal failure, this would result in significant inelastic deformation due to increasing effective stress, similar to that observed in depleting chalk gas reservoirs (e.g. Keszthelyi et al., 2014). This combination of cementation and compaction could therefore create high-density geobodies of diagenetic origin.

Model (C)

We propose the following scenario for the formation of diagenetic geobodies delineated by SCRs: 1) accumulation of basinal fluids below the Chalk Group (Fig. 18); 2) Differential compaction of the Triassic-Jurassic basin fill resulting in fault reactivation and failure of major seals (e.g. lowermost Chalk Group, RPM and base Paleocene clays, Figs. 12d and 19). Subsequently, trapped fluids started to escape from the Chalk Group through a system of fault/fracture swarms and permeable beds, and were temporarily trapped locally below intra-chalk seals. Reduced pore pressure resulted in mechanical compaction. 3) This was followed by cementation of high Mncalcite/dolomite/magnesium sulphates from the extra-formational fluids. The pathway of the fluids is reflected by the 3D geometry of the SCRs, which follows a zigzagging and widening upward pattern starting from the RPM (Fig. 12).

Step 1: accumulation of basinal fluids (D)

SCRs occur at locations in the basin where thick sedimentary basins underlie the Chalk Group (Fig. 16) and where pronounced fault systems occur (Figs 12, 14 and 17). In the absence of hydrocarbon emplacement, the occurrence of high-porosity chalk above the RPM is likely the result of early establishment of overpressure, which originates from non-equilibrium compaction of the chalk, and from a transference component (c.f. Japsen, 1998). Compaction of the 4-km thick Triassic-Jurassic succession and dehydration of the marine mudstones may have generated a large amount of fluid, which remained contained beneath major seals within the Jurassic basin, generating overpressure. Because of the multiple orientations and interlinkage of the fault systems and zones (Fig. 17), large basinal drainage areas were established and funnelled basinal fluids towards the base of the chalk at the crest of the Ryan Anticline and along the Coffee Soil Fault, where 'winged' low-velocity zones occur that may reflect these fluids (Figs 18 and 20, Step 1).

This article is protected by copyright. All rights reserved. 
Step 2-4: Location of the SCRs dictated by the underlying fault system (D)

During reactivation of the faults, or when critical pore pressure levels were reached, these seals failed and fluids migrated along permeable zones such as fault planes into the lowermost parts of the chalk (Fig. 20, Step 2-4). These fluids could generally be contained below the early cemented chalk underneath the RPM, though raised $\mathrm{Mn} / \mathrm{Sr}$ ratios indicate that some fluid penetrated upward (Figs 5 and 12c).

Differential compaction would be a feasible driving force for seal failure (Fig. 20 Step 2), and movement is most pronounced at the crest of the Ryan Anticline (transition from salt pillow to Mesozoic basin), Ringkøbing-Fyn High (transition from Mesozoic basin to basement), and on top of salt diapirs (halokinesis). The increase in shear stress generated by differential compaction exceeded the failure envelope, leading to brittle deformation within the chalk, as indicated by the upward propagation of the underlying faults into the chalk, visible as high-angle ( $30-55^{\circ}$ to the normal) subtle linear contrasts in acoustic impedance (Figs 10, 12e, f, 20, Step 3 and 4). Comparison of these geometries with chalk outcrops from Selwicks Bay (UK), suggests that these lineations could represent low-throw faults and fracture swarms, which can act as fluid conduits (cf. Starmer, 1995). The spatial correlation between the SCRs and underlying fault fabric points to this genetic relationship (Figs 13, 15 and 17). Continued differential compaction may thus have generated many episodes of fault reactivation, which eventually also offset the sealing low-porosity chalk beneath the RPM and the sealing clays on top of the chalk at the crest of O-1X (see Figs 9, 13, 19 and 20, Step $5)$.

Step 5 and 6: Overpressure leak-off and intra-chalk spreading pattern (D)

A significant offset of the sealing clays on top of the chalk might have compromised their sealing capacity (Figs 19 and 20, Step 5). The overlying polygonally faulted clays probably did not form a seal either (see Cartwright 2007 for a discussion), so it is possible that the overpressured and newly transferred fluids could start to escape the chalk on a large scale. Draining of overpressure from this 'valve' initiated mechanical compaction of the chalk, which in turn induced further displacement on the surrounding faults and further offset the seal on top of the chalk (Fig. 20, Step 5).

In this scenario, compaction would be followed by precipitation of very negative $\delta^{18} O$ pore-filling cement from ascending basinal fluids, rich in $\mathrm{Mg} / \mathrm{Mn}$ minerals (e.g. extra-formational fluids) (Fig. 20, Step 6). The fluids ascended into the chalk following existing structural weaknesses, and/or induced hydraulic fracturing (Sachau et al., 2015, Figs 10 and 12). The strong correlation between the orientation of the faults and the SCRs (Fig. 17) suggests that highly permeable zones were established where the N-S and NW-SE oriented faults crossed. Fault brecciation is common at these junctions (Caine et al., 1996).

This article is protected by copyright. All rights reserved. 
The fluids spread laterally mainly at four stratigraphic levels which are associated with condensed sections/hiatuses, and which possibly contain early cemented horizons: 1) below the Early Campanian Unconformity (ECU, Top Kraka Formation, CK-3); 2) Top Campanian Unconformity (RPM, Top Gorm Formation, CK-5, Fig. 12c); 3) near the top of the Tor Formation (CK-6, Fig. 12e); and 4) at the top of the Ekofisk Formation (CK-7, Fig. 12f). The fluids initiated precipitation of manganese-rich calcite cement (high $\mathrm{Mn} / \mathrm{Sr}$ ratios) at the base of the chalk, and likely within the SCRs (inferred from Zone 3 and seismic anomaly, Figs 5 and 12), indicating large water:rock interaction (Fig. 8b). The sulphates found at the fault plane, with Triassic-Permian sulphur signature, might also be sourced this way (Fig. 13a).

Analogues (B)

The zigzagging geometry of the SCRs strikingly resembles geometries of seismic-scale dolostones formed by infiltration of Mg-rich fluids into limestone host rocks (Sharp et al., 2010; Martín-Martín et al., 2015). Migration of the Mg-rich fluids was largely controlled by faults, fractures and fissures, in addition to porous beds and stylolites, which together lead to a large-scale zigzagging geometry. The structural texture was controlled by tectonic stresses acting on the rocks and the pore fluid pressure (Bons et al., 2012). When fluid pressure increases, tensile stresses can become large enough for the rock to undergo brittle failure and form extensional fractures. These can provide both fluid pathways and space for crystallization of minerals. A similar pattern is recognized in the Ryan Anticline as $\mathrm{Mg} / \mathrm{Mn}$-rich fluids entered the Chalk Group, precipitating cements rich in those elements. Since the chalk generally has high purity, then if the change in the porosity, the amount of minerals other than calcite, and/or contact cement is large enough, the resulting structures might be within seismic resolution, the pathways will be visible on 3D seismic data. The methodology and insights, however, are not limited only to chalk and can be used to understand fluid migration elsewhere.

\section{Concepts in the seismic chalk paradigm (B)}

There are three key processes that generate heterogeneity in chalk: 1) (re-)depositional processes (e.g. bottom currents and mass-waste deposits); 2) tectonic deformation (e.g. fractures and faults); and 3) diagenetic overprinting. Diagenesis is demonstrated here to have large impact on regional and local seismic patterns. This interpretation therefore adds an important concept to the seismic chalk paradigm, which until now was dominated by sedimentary and structural seismic heterogeneities. In order to distinguish between the different processes forming heterogeneity, it is key to use an integrated methodology as presented in our study.

This article is protected by copyright. All rights reserved. 
The recognition of seismic-scale diagenesis in the Chalk Group has implications for hydrocarbon exploration, reservoir characterization, and production. Similar features cross-cutting stratigraphy have been recognized in other parts of the basin that contain producing oil fields, for example around diapirs (Skjold, Gorm, Nils), in the Roar Gas Field (c.f. Esmerode et al., 2008; Back et al., 2011), and in the German North Sea Sector (Arfai et al., 2015). Investigating these SCRs with the same methodology will provide further insights into the fluid migration history and potential faultbound diagenesis within the chalk, but with hydrocarbon emplacement as an additional complicating factor. Production at the Tyra (DK) Valhall, Elgin, and Ekofisk fields (NO) has already led to significant compaction of the reservoir and seafloor subsidence (meter-to decameter-scale), and this is expected to increase with further production (Keszthelyi et al., 2016). The Ryan Anticline SCRs could provide a natural analogue to these fields, but where reservoir compaction is a result of overpressure loss because of top seal failure.

Finally, the timing of the formation of the SCRs is crucial. If the fluid leak-off occurs after the main phase of hydrocarbon generation, the SCRs could represent breached reservoirs. At present we are unable to determine this since, in the case of open-system diagenesis, fluid constraints are needed in order to arrive at a meaningful absolute precipitation temperature with the use of classical oxygen isotope paleo-temperature functions (Craig, 1957). In order to circumvent this problem, future work will focus on clumped isotope paleo-temperature measurements as described in Swart (2015).

\section{Conclusions (A)}

- By using a combination of geophysical, petrophysical, petrological, and geochemical data presented in a 3D geological context, seismic-scale diagenesis in the Chalk Group has been recognized. The methodology and insights presented here can potentially be applied elsewhere and improve our general understanding of fluid migration, seal failure, and diagenesis.

- The study focused on two specific types of seismic markers identified in the Chalk Group:

1) A regionally continuous seismic marker, the Regional Porosity Marker (RPM), which represents a locally erosive, stratigraphic surface that separates high-porous chalks above from low-porous chalks below. It is dated as Top Campanian, represents a hiatus and condensation zone, shows early cementation and is interpreted to have formed as a result of erosion and/or non-deposition due to increased ocean bottom currents. This interval formed an important intra-chalk seal, trapping large amounts of ascending fluids until seal breach led to fluid escape into the overlying high-porous chalks.

2) Local Stratigraphy Cross-cutting Reflectors (SCRs), which have a variety of expressions (V-, $\mathrm{W}$ - and 2-W-shapes) in 2D section, and develop a zigzagging geometry through the stratigraphy, delineate fault-bound high-density chalk geobodies nested inside highporosity chalk. Their stratigraphic distribution is limited to the chalk above the RPM marker (i.e., the Tor and Ekofisk formations). The geographical distribution of the SCRs is closely related to the underlying fault fabric.

- The similarity between the geochemical character of the chalk beneath the RPM and within the SCR-delineated geobodies (increased $\mathrm{Mn} / \mathrm{Sr}$ ratios), and the fact that the SCRs never cut through the RPM, suggest that pore-filling cementation first occurred in low-porosity chalk below the RPM (characterised by a large amount of early cementation and some late cement), and later

This article is protected by copyright. All rights reserved. 
within the SCR-delineated chalk bodies (characterised by large amount of late cement). The chalk beneath the RPM would thus have formed an important seal where the Mesozoic fluids stagnated.

- SCR formation was likely initiated by differential subsidence of the Triassic/Jurassic sedimentary basin, leading to reactivation of the faults and their propagation up through the Chalk Group, followed by failure of seals throughout the Cretaceous and lower Paleocene succession. This rupturing of pressure compartments resulted in draining of overpressure followed by mechanical compaction, and caused large fluxes of basinal fluids to pass through the Chalk Group.

- The width of the diagenetic geobodies delineated by the SCRs increases upward from the RPM (Top Gorm Formation), to the top of the Tor Formation, and to the top of the Ekofisk Formation. This is interpreted to reflect the (temporary) sealing capacity of the Formation tops and associated cement precipitation.

- The concept of seismic-scale diagenesis, its implications for hitherto unrecognised heterogeneities, and its potential for fluid migration pathways, may provide new insights for hydrocarbon exploration and production in the chalks of the North Sea Basin.

\section{Acknowledgements (A)}

The authors kindly acknowledge the Danish Underground Consortium (Shell, Chevron, Maersk Oil, and Nordsøfonden) for providing seismic and well data and the permission to publish the results. Frederic Armour and Solomon Seyum (DTU) are kindly thanked for technical discussions.

Schlumberger is acknowledged for providing Petrel E\&P and eXchroma ${ }^{\mathrm{SG}}$ chromatic geology plug-in, Eliis for PaleoScan ${ }^{\mathrm{TM}}$, and ffA GeoTeric for providing GeoTeric software suits. Wolfgang Weinzierl (Schlumberger) is kindly thanked for sharing his extensive knowledge of Petrel. Ingelise Schmidt (Maersk Oil) is kindly thanked for providing access to the core facilities and the usage of the SEM. Reviewers Ida Fabricius, Thilo Wrona and Matteo Gennaro are kindly thanked for providing corrections and comments that helped to improve an earlier version of the manuscript. Edward Harris and Ellen Keerd are thanked for checking for spelling errors. There is no conflict of interest for any of the authors.

\section{References (A)}

Anderskouv, K. \& SURLYK, F. (2012) The Influence of Depositional Processes on the Porosity of Chalk. Journal of the Geological Society, 169, 311-325.

ARCHIE, G.E. (1942) The Electrical Resistivity Log as an Aid in Determining Some Reservoir Characteristics. Transactions of the AIME, 146, https://doi.org/10.2118/942054-G.

Arfal, J., LUtZ, R., Franke, D., Gaedicke, C. \& Kley, J. (2015) Mass-Transport Deposits and Reservoir Quality of Upper Cretaceous Chalk within the German Central Graben, North Sea. International Journal of Earth Sciences, 105, 797-818.

Back, S., Van Gent, H., Reuning, L., Grotsch, J., Niederau, J. \& Kukla, P. (2011) 3d Seismic Geomorphology and Sedimentology of the Chalk Group, Southern Danish North Sea. Journal of the Geological Society, London, 168, 393-405.

This article is protected by copyright. All rights reserved. 
BANNER, J.L. \& HANSON, G.N. (1990) Calculation of Simultaneous Isotopic and Trace Element Variations During Water-Rock Interaction with Applications to Carbonate Diagenesis. Geochimica et Cosmochimica Acta, 54, 3123-3137.

Bons, P.D., ElBuRG, M.A. \& Gomez-Rivas, E. (2012) A Review of the Formation of Tectonic Veins and Their Microstructures. Journal of Structural Geology, 43, 33-62.

Boussaha, M., ThIBAULT, N. \& StemmerIK, L. (2016) Integrated Stratigraphy of the Late Campanian \&\#8211; Maastrichtian in the Danish Basin: Revision of the Boreal Calcareous Nannofossil Zonation. Newsletters on Stratigraphy, 49, 337-360.

BREWSTER, J. \& DANGERFIELD, J.A. (1984) Chalk Fields Along The Lindesness Ridge, Eldfisk. Marine and Petroleum Geology, 1, 239 - 278.

Brown, D.A. (1987) The Flow of Water and Displacement of Hydrocarbons in Fractured Chalk Reservoirs. Geological Society, London, Special Publications, 34, 201-218.

BulHöES, E.M., NogueIRA De AMORIM, W. (2005) Princípio de SismoCamada Elementar e sua aplicação à Técnica Volume de Amplitudes (TecVA). Sociedade Brasileira de Geofísica, $9^{\text {th }}$ International Congress of the Brazilian Geophysical Society, 1382-1387.

CAINE, J.S., EVANS, J.P. \& ForSter, C.B. (1996) Fault Zone Architechture and Permeability Structure. Geology, 24, 1025-1028.

CARTWRIGHT, J. (1989) The kinematics of inversion in the Danish Central Graben. Geological Society, London, Special Publications, 44, 153-175.

CARTWRIGHT, J. (2007) The impact of 3D seismic data on understanding compaction, fluid flow, and diagenesis in sedimentary basins. Geological Society, London, 164, 881-893.

CherRet, A.J., Escobar, I. \& HANSEN, H.P. (2011). Fast Deterministic Geostatiscal Inversion. In 73rd EAGE Conference and Exhibition incorporating SPE EUROPEC 2011.

Coward, M.P., Dewwey, J.R., Hempton, M., Holroyd, J. \& Mange.M.A. (2003). Chapter 2: Tectonic Evolution. In: The Millennium Atlas: Petroleum Geology of the Central and Northern North Sea

(Ed. by D. Evans, C. Graham, A. Armour \& P. Bathurst), 1, 157-189. The Geological Society of London, London.

CRAIG, H. (1957) Isotopic standards for carbon and oxygen and correction factors for massspectrometric analysis of carbon dioxide. Geochimica et cosmochimica acta, 12, 133-149.

D'HEUR, M. (1984) Porosity and hydrocarbon distribution in the North Sea Chalk reservoirs, Marine and Petroleum Geology, 1, 223-238

EgeberG, P.K. \& SAIGAL, G.C. (1991) North Sea Chalk Diagenesis: Cementation of Chalks and Healing of Fractures. Chemical Geology, 92, 339-354.

This article is protected by copyright. All rights reserved. 
El Husseiny, A. \& Vanorio, T. (2015) The Effect of Micrite Content on the Acoustic Velocity of Carbonate Rocks. Geophysics, 80, L45-L55.

Esmerode, E. V., Lykke-Andersen, H., \& Surlyk, F. (2007). Ridge and valley systems in the Upper Cretaceous chalk of the Danish Basin: contourites in an epeiric sea. Geological Society, London, Special Publications, 276(1), 265-282.

ESMERODE, E.V., LYKKe-ANDERSEN, H. \& SURLYK, F. (2007) Ridge and valley systems in the Upper Cretaceous chalk of the Danish Basin: contourites in an eiperic sea. .

ESMerode, E.V., LYKKE-ANDERSEN, H. \& SURLYK, F. (2008) Interaction between Bottom Currents and Slope Failure in the Late Cretaceous of the Southern Danish Central Graben, North Sea. Journal of the Geological Society, 165, 55-72.

ESMerode, E.V. \& SURLYK, F. (2009) Origin of Channel Systems in the Upper Cretaceous Chalk Group of the Paris Basin. Marine and Petroleum Geology, 26, 1338-1349.

Faÿ-Gomord, O., Soete, J., Katika, K., Galaup, S., CAline, B., Descamps, F., Lasseur, E., FABricius, I.L., SAÏAG, J., SWENNEN, R. \& VANDYCKE, S. (2016) New Insight into the Microtexture of Chalks from Nmr Analysis. Marine and Petroleum Geology, 75, 252-271.

FABRICIUS, I.L. (2003) How Burial Diagenesis of Chalk Sediments Controls Sonic Velocity and Porosity. AAPG Bulletin, 87, 1755-1778.

FABRICIUS, I.L. (2007) Chalk: Composition, Diagenesis and Physical Properties. Bulletin of the Geological Society of Denmark, 55, 97-128.

FABRICIUS, I.L. \& BORRE, M.K. (2007) Stylolites, Porosity, Depositional Texture, and Silicates in Chalk Facies Sediments. Ontong Java Plateau ? Gorm and Tyra Fields, North Sea. Sedimentology, 54, 183-205.

FABRICIUS, I.L. (2014) Burial Stress and Elastic Strain of Carbonate Rocks. Geophysical Prospecting, 62, 1327-1336.

FRASER, S.I., ROBINSON, A.M., JOHNSON, H.D., UNDERHILL, J.R., KADOLSKY, D.G.A., CONNELL, R., JOHANNESEN, P. \& RAVNÅS, R. (2002) Upper Jurassic. In: The Millennium Atlas: Petroleum Geology of the Central and Northern North Sea

(Ed. by D. Evans, C. Graham, A. Armour \& P. Bathurst), 1, 157-189. The Geological Society of London, London.

FRITSEN, A. (1999) A Joint Chalk Stratigraphic Framework. In: Joint Chalk Research Program Topic $V$ (Ed. by, 1, 206. Norwegian Petroleum Directorate.

Gaviglio, P., Bekri, S., VAndycke, S., Adler, P.M., Schroeder, C., Bergerat, F., Darquennes, A. \& Coulon, M. (2009) Faulting and Deformation in Chalk. Journal of Structural Geology, 31, 194-207.

GENNARO, M. (2011) 3D seismic stratigraphy and reservoir characterization of the Chalk Group in the Norwegian Central Graben, North Sea. PhD dissertation, University of Bergen

This article is protected by copyright. All rights reserved. 
Gennaro, M., Wonham, J.P., SAelen, G., Walgenwitz, F., Caline, B. \& Fä̈-Gomord, O. (2013) Characterization of dense zones within the Danian chalks of the Ekofisk Field, Norwegian North Sea, Petroleum Geoscience, 19, 39-64

Gennaro, M. \& Wonham, J.P. (2014) Channel Development in the Chalk of the Tor Formation, North Sea (Ed. by, 551-586. John Wiley \& Sons, Ltd, Chichester, UK.

GlenNie, K.W., Higham, J. \& StemmerIK, L. (2003) Permian. In: The Millennium Atlas: Petroleum Geology of the Central and Northern North Sea (Ed. by D. Evans, C. Graham, A. Armour \& P. Bathurst), 91-103. The Geological Society of London, London.

Goldsmith, P.J., Hudsen, G. \& VAn Veen, P. (2003) Triassic. In: The Millennium Atlas: Petroleum Geology of the Central and Northern North Sea (Ed. by D. Evans, C. Graham, A. Armour \& P. Bathurst), 1, 105-127. The Geological Society of London, London.

Gommesen, L., Fabricius, I.L., MukerJI, T., Mavko, G. \& Pedersen, J.M. (2007) Elastic Behaviour of North Sea Chalk: A Well-Log Study. Geophysical Prospecting, 55, 307-322.

HANCOCK, J.M. (1975) The Petrology of the Chalk. Proceedings of the Geologists' Association, 86, 499535.

HARDING, R. \& HUUSE, M. (2015) Salt on the Move: Multi Stage Evolution of Salt Diapirs in the Netherlands North Sea. Marine and Petroleum Geology, 61, 39-55.

HARDMAN, R.F.P. (1982) Chalk Reservoirs of the North Sea. Geological Survey of Denmark and Greenland Bulletin, 30, 119-137.

HAWKINS, K. (2008) Defining the Extent of the Compacting Elgin Reservoir by Measuring StressInduced Anisotropy. First Break, 26, 81-88.

Hu, X., JeAns, C. \& DiCKSON, T. (2012) Geochemical and Stable Isotope Patterns of Calcite Cementation in the Upper Cretaceous Chalk, Uk: Direct Evidence from Calcite-Filled Vugs in Brachiopods. Acta Geologica Polonica, 62, 143-172.

INESON, J.R., BOJESEN-KOEFOED, J.A., DYBKJJER, K. \&N NIELSEN, L.H. (2003) Volghian-Ryazanian 'hot shales' of the Bo Member (Farsund Formation) in the Danish Central Graben. Geological Survey of Denmark and Greenland Bulletin, 1, 403-436

JAPSEN, P. (1998) Regional Velocity-Depth Anomalies, North Sea Chalk: A Record of Overpressure and Neogene Uplift and Erosion. AAPG Bulletin, 82, 2031-2074.

JAPSEN, P. (1999) Overpressured Cenozoic Shale Mapped from Velocity Anomalies Relative to a Baseline for Marine Shale, North Sea. Petroleum Geoscience, 5, 321-336.

JAPSEN, P., Britze, P. \& Andersen, C. (2003) Upper Jurassic - Lower Cretaceous of the Danish Central Graben: structural framework and nomenclature. Geological Survey of Denmark and Greenland Bulletin, 1, 233-246

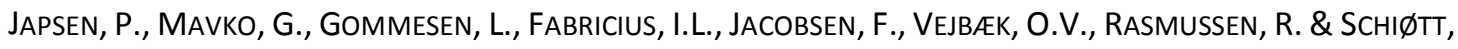
C.R. (2005). Chalk Background Velocity: Influence of Effective Stress and Texture. 67th EAGE

This article is protected by copyright. All rights reserved. 
Conference \& Exhibition, European Association of Geoscientists \& Engineers Publications B.V. (EAGE).

JENSENIUS, J. \& MUNKSGAARD, N.C. (1989) Large Scale Hot Water Migration Systems around Salt Diapirs in the Danish Central Trough and Their Impact on Diagenesis of Chalk Reservoirs. Geochimica et Cosmochimica Acta, 53, 79-87.

JUnG, C., VoIGt, S., FrIedrich, O., KoCH, M. C., \& Frank, M. (2013) Campanian-Maastrichtian ocean circulation in the tropical Pacific. Paleoceanography, 28, 562-573.

KARLO, J.F., VAN BuCHEM, F.S.P., Moen, J. \& MilRoy, K. (2014) Triassic-Age Salt Tectonics of the Central North Sea. Interpretation, 2, SM19-SM28.

KeSzThelyI, D., Dysthe, D.K. \& JamtVeit, B. (2016) Compaction of North-Sea Chalk by Pore-Failure and Pressure Solution in a Producing Reservoir. Frontiers in Physics, 4, 1-10.

KYRKJEB $\varnothing$, R., GABRIELSEN, R. \& FALEIDE, J. (2004) Unconformities related to the Jurassic-Cretaceous synrift-postrift transition of the northern North Sea.Journal of the Geological Society, 161, 117.

Lieberkind, K., BANG, I., MiKKelSen, N. \&NYGAARD, E. (1982) Late Cretaceous and Danian limestone. In: Michelsen, O. (ed.) Geology of the Danish Ncetral Grben, Geological Survey of Denmark, Series B, 8, 49-62.

LYKKE-ANDERSEN, H. \& SURLYK, F. (2004) The Cretaceous-Palaeogene Boundary at Stevns Klint, Denmark: Inversion Tectonics or Sea-Floor Topography? Journal of the Geological Society, 161, 343-352.

LAAKE, A. (2013). Structural Interpretation in Color-a New Rgb Processing Technique for Extracting Geological Structures from Seismic Data. SEG Technical Program Expanded Abstracts 2013, Society of Exploration Geophysicists.

MalLon, A.J. \& SWARBRICK, R.E. (2002) A Compaction Trend for Non-Reservoir North Sea Chalk. Marine and Petroleum Geology, 19, 527-539.

Martín-Martín, J.D., Travé, A., Gomez-Rivas, E., Sizun, J.P., Salas, R., Gómez-Gras, D., Vergés, J., SCIENCES, E. \& ALMERA, J. (2010) Fault-Associated Dolomites in the Benicàssim Area, Maestrat Basin , E . Spain - Macro- to Micro- Scale Fluid Flow in Carbon. Eage, 14-17.

Megson, J.B. (1992) The North Sea Chalk Play: Examples from the Danish Central Graben. Geological Society, London, Special Publications, 67, 247-282.

MiChelsen, O., Nielsen, L.H., Johannesen, P.N., ANDSBJerg, J. \& SuRlyk, F. (2003) Jurassic Lithostratigraphy and Stratigraphic Development Onshore and Offshore Denmark. Geological Survey of Denmark and Greenland Bulletin, 1, 147-216.

MOLENAAR, N. \& ZIJLSTRA, J.J.P., (1997) Differential early diagenetic Low-Mg calcite cementation and rhythmic hardground development in Campanian - Maastrichtian chalk. EAGE Sedimentary Geology, 109, 261-281.

This article is protected by copyright. All rights reserved. 
Morozov, P., Paton, G., Milyushinin, A.M., Kiselev, V.V., LlC, S., Myasoedov, D.N. \& LlC, L. (2013) Application of High Definition Frequency Decomposition Techniques on Western Siberia Reservoirs. EAGE Tyumen 2013, 2013-2013.

OGg, J.G., OGG, G. \& Gradstein, F.M. (2016) A Concise Geological Time Scale. Elsevier.

PARTYKA, G., GRIDLEY, J. \& LOPEZ, J. (1999) Interpretational Applications of Spectral Decomposition in Reservoir Characterization. The Leading Edge, 18, 353-360.

Pauget, F., LACAZE, S. \& Valding, T. (2009). A Global Approach in Seismic Interpretation Based on Cost Function Minimization, Society of Exploration Geophysicists.

Pedersen, S.I., Randen, T., Sonneland, L. \& Steen, Ø. (2003). Automatic Fault Extraction Using Artificial Ants, In: Mathematical Methods and Modelling in Hydrocarbon Exploration and Production, 107-116.

Posamentier, H.W., Davies, R.J., CarTWRight, J.A. \& Wood, L. (2007) Seismic Geomorphology - an Overview. Geological Society, London, Special Publications, 277, 1-14.

QUINE, M. \& BOSENCE, D. (1991) Stratal Geometries, Facies and Sea-Floor Erosion in Upper Cretaceous Chalk, Normandy, France. Sedimentology, 38, 1113-1152.

RASMUSSEN, E.S. (2013) Cenozoic Structures in the Eastern North Sea Basin - a Case for Salt Tectonics: Discussion. Tectonophysics, 601, 226-233.

Regnet, J.B., Robion, P., DAvid, C., Fortin, J., Brigaud, B. \& YVen, B. (2015) Acoustic and Reservoir Properties of Microporous Carbonate Rocks: Implication of Micrite Particle Size and Morphology. Journal of Geophysical Research: Solid Earth, 120, 790-811.

RøSTE, T. (2007) Monitoring Overburden and Reservoir Changes from Prestack Time-Lapse Seismic Data - Applications to Chalk Fields. Doctoral Thesis, NTNU, Trondheim.

SACHAU, T., BONS, P. D., \& GomeZ-RIVAS, E. (2015) Transport efficiency and dynamics of hydraulic fracture networks, Frontiers in Physics, 3, 63.

SChiøler, P., Andsbjerg, J., Clausen, O.R., Dam, G., Dybkjer, K., Hamberg, L., Heilmann-Clausen, C., JohANnessen, E.P., KRISTENSEN, L.E., PrINCE, I. \& RASMUSSEN, J.A. (2007) Lithostratigraphy of the Palaeogene - Lower Neogene succession of the Danish North Sea, Geological Survey of Denmark and Greenland Bulletin, 12, 1-77

SCHOlle, P.A. \& HAlley, R.B. (1985) Burial Diagenesis: Out of Sight, out of Mind! In: Carbonate Sedimentology and Petrology (Ed. by P. A. Scholle, N. P. James \& J. F. Read), 36, 135-160. American Geophysical Union, Washington, D. C.

Sharp, I., Gillespie, P., Morsalnezhad, D., TAberner, C., Karpuz, R., Vergés, J., Horbury, A., Pickard, N., GARLAND, J. \& HUNT, D. (2010) Stratigraphic Architecture and Fracture-Controlled Dolomitization of the Cretaceous Khami and Bangestan Groups: An Outcrop Case Study, Zagros Mountains, Iran. Geological Society, London, Special Publications, 329, 343-396.

SHERIFF, R.E. (2010) Nomogram for Fresnel-zone calculation. Geophysics, 45, 968-972.

This article is protected by copyright. All rights reserved. 
SIMONSEN, L. \& TOFT, J. (2006) Texture, Composition and Stratigraphy of Volcanic Ash Beds in Lower Palaeocene Chalk from the North Sea Central Graben Area. Marine and Petroleum Geology, 23, 767-776.

SMIT, F.W.H. (2014) Seismic Stratigraphy, Basin Evolution, and Seismic Geomorphology of the Late Cretaceous and Earliest Paleocene Chalk Group in the Danish Central Graben. MSc Thesis Thesis, Aarhus University.

SMIT, F.W.H., VAN BUCHEM, F.S.P., SCHMIDT, I., STEMMERIK, L. (2017) Updated seismic geomorphologal workflow applied to the Chalk Group. Society of Exploration Geophysicists, SEG Technical Program Expanded Abstracts 2017, 1976-1981

StARMER, I.C. (1995) Deformation of the Upper Cretaceous Chalk at Selwicks Bay, Flamborough Head, Yorkshire: Its Significance in the Structural Evolution of North-East England and the North Sea Basin. Proceedings of the Yorkshire Geological Society, 50, 213-228.

SURlyk, F., Dons, T., Clausen, C.K. \& Higham, J. (2003) Upper Cretaceous. In: The Millennium Atlas: Petroleum Geology of the Central and Northern North Sea (Ed. by D. Evans, C. Graham, A. Armour \& P. Bathurst), 1, 213-233. The Geological Society of London, London.

SWART, P.K. (2015) The Geochemistry of Carbonate Diagenesis: The Past, Present and Future. Sedimentology, 62, 1233-1304.

THIBAULT, N., \& GARDIN, S. (2006) Maastrichtian calcareous nannofossil biostratigraphy and paleoecology in the Equatorial Atlantic (Demerara Rise, ODP Leg 207 Hole 1258A). Revue de micropaléontologie, 49, 199-214.

VAN BUCHEM, F.S.P., SMIT, F.W.H., BUIJS, G.J.A., TRUDGILL, B. \& LARSEN, P.H. (2018) Tectonostratigraphic Framework and Depositional History of the Cretaceous-Danian Succession of the Danish Central Graben (North Sea) - New Light on a Mature Area. In: Petroleum Geology of NW Europe: 50 years of learning - Proceedings of the $8^{\text {th }}$ Petroleum Geology Conference (Ed. by Bowman, M. \& Levell, B.), Geological Society of London, 9-46.

VAN DER MOLEN, A. (2004) Sedimentary development, seismic stratigraphy and burial compaction of the CHalk Group in the Netherlands. PhD dissertation, Utrecht University

VeJBAEK, O.V. \& ANDERSEN, C. (2002) Post Mid-Cretaceous Inversion Tectonics in the Danish Central Graben - Regionally Synchronous Tectonic Events? Bulletin of the Geological Society of Denmark, 49, 139-144.

Vejbek, O.V., Frykman, P., BeCH, N. \& Nielsen, C.M. (2005) The History of Hydrocarbon Filling of Danish Chalk Fields (Ed. by, 12, 1331-1345. Geological Society of London.

Vejbeek, O.V., Bidstrup, T., Britze, P., Erlström, M., Rasmussen, E.S. \& Sivhed, U. (2007) Chalk Depth Structure Maps, Central to Eastern North Sea, Denmark. Geological Survey of Denmark and Greenland Bulletin, 15, 9-12.

WAGNER, H., (2014) Tove Acoustic Inversion. Maersk Oil in-house report GST QI Geophysics

This article is protected by copyright. All rights reserved. 


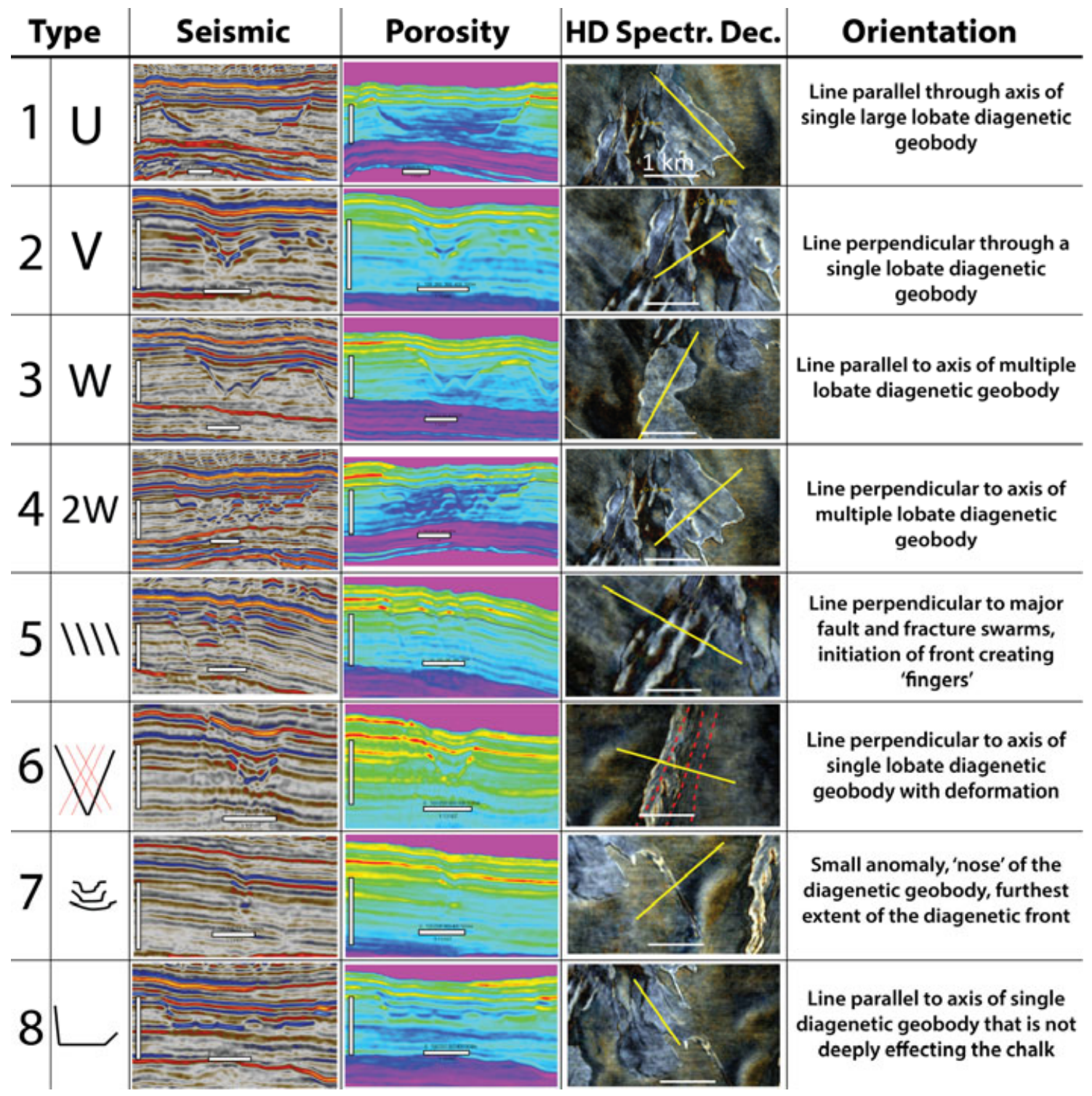

This article is protected by copyright. All rights reserved. 


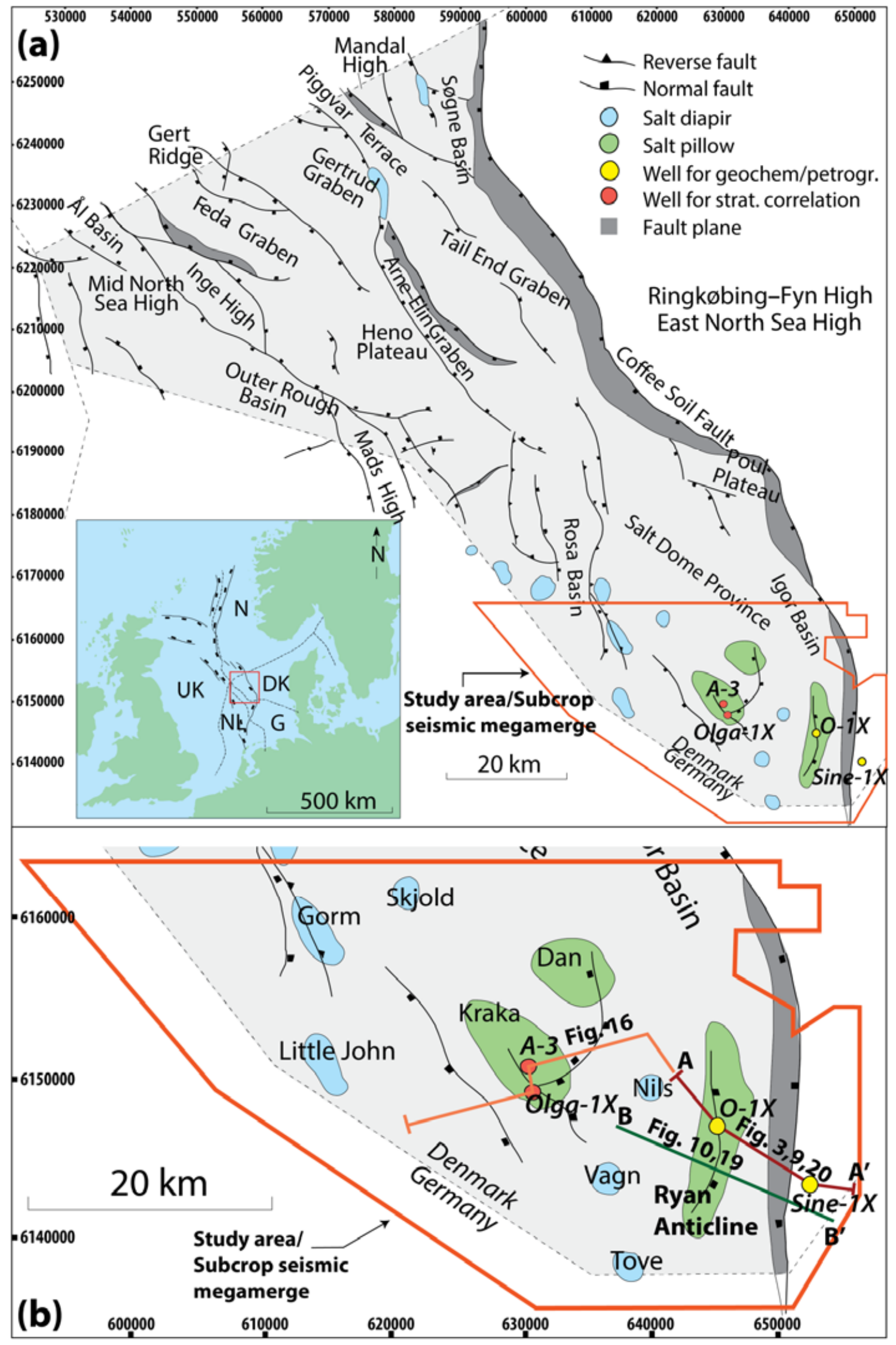

This article is protected by copyright. All rights reserved. 

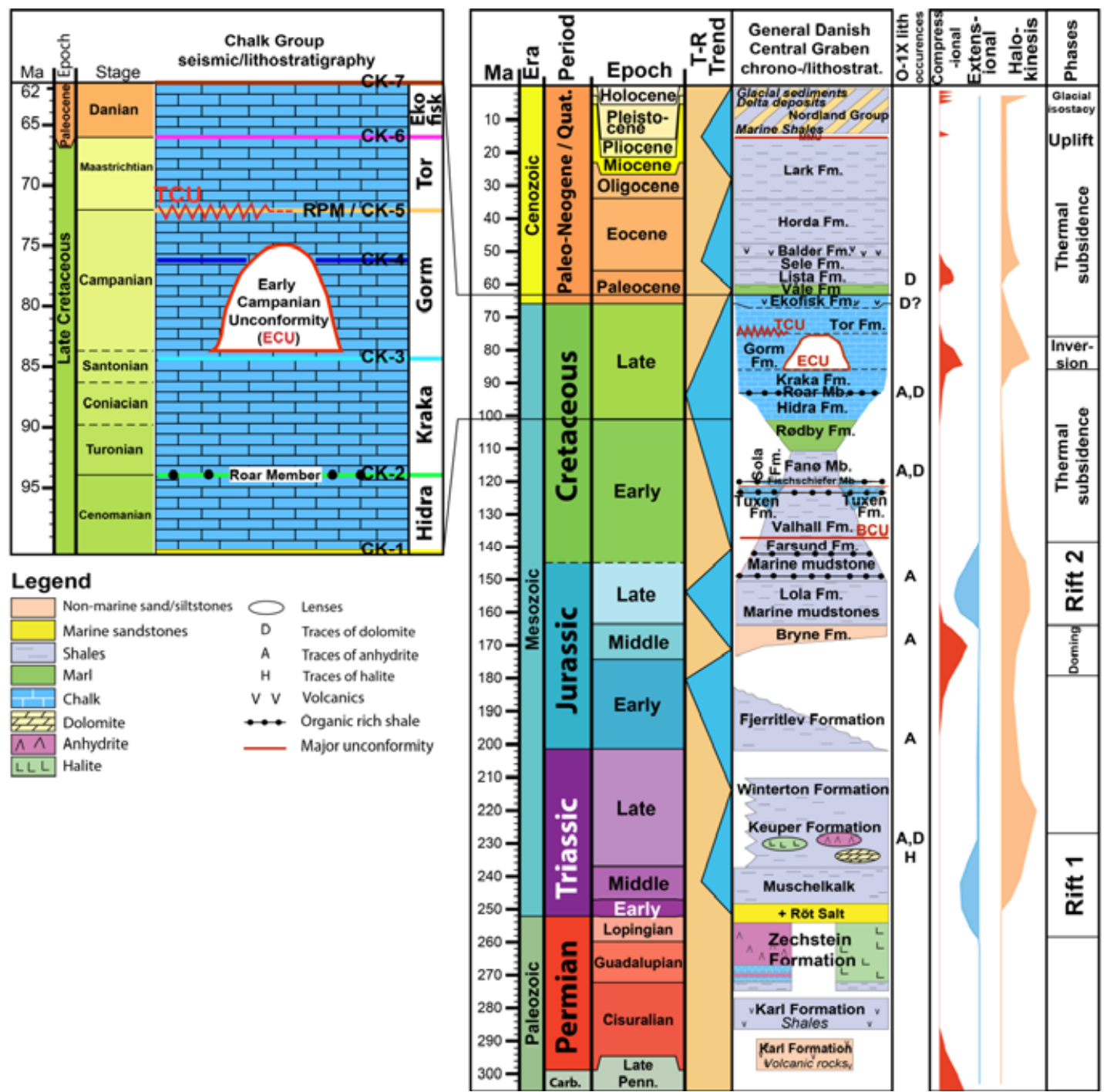

This article is protected by copyright. All rights reserved. 


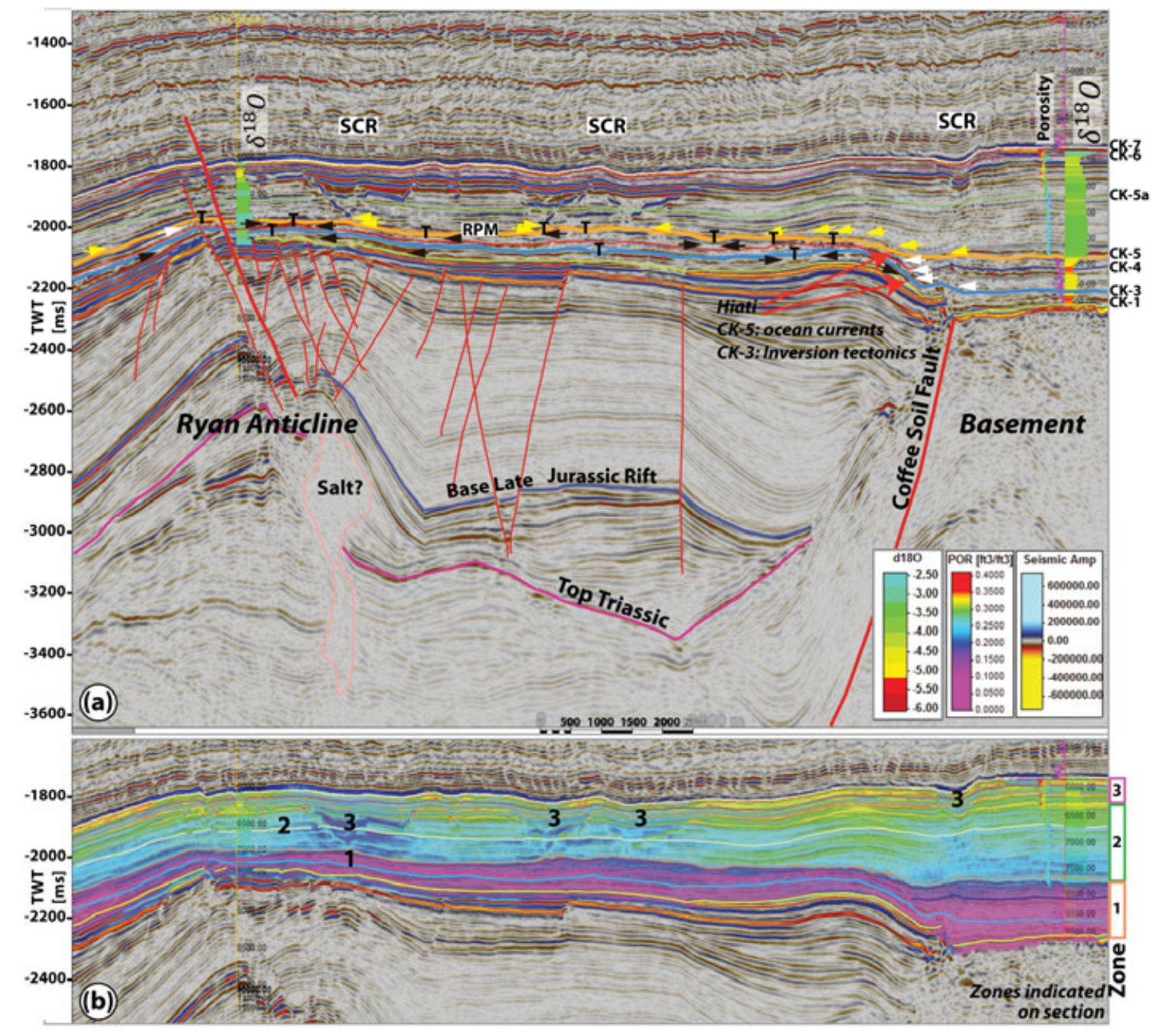

This article is protected by copyright. All rights reserved. 

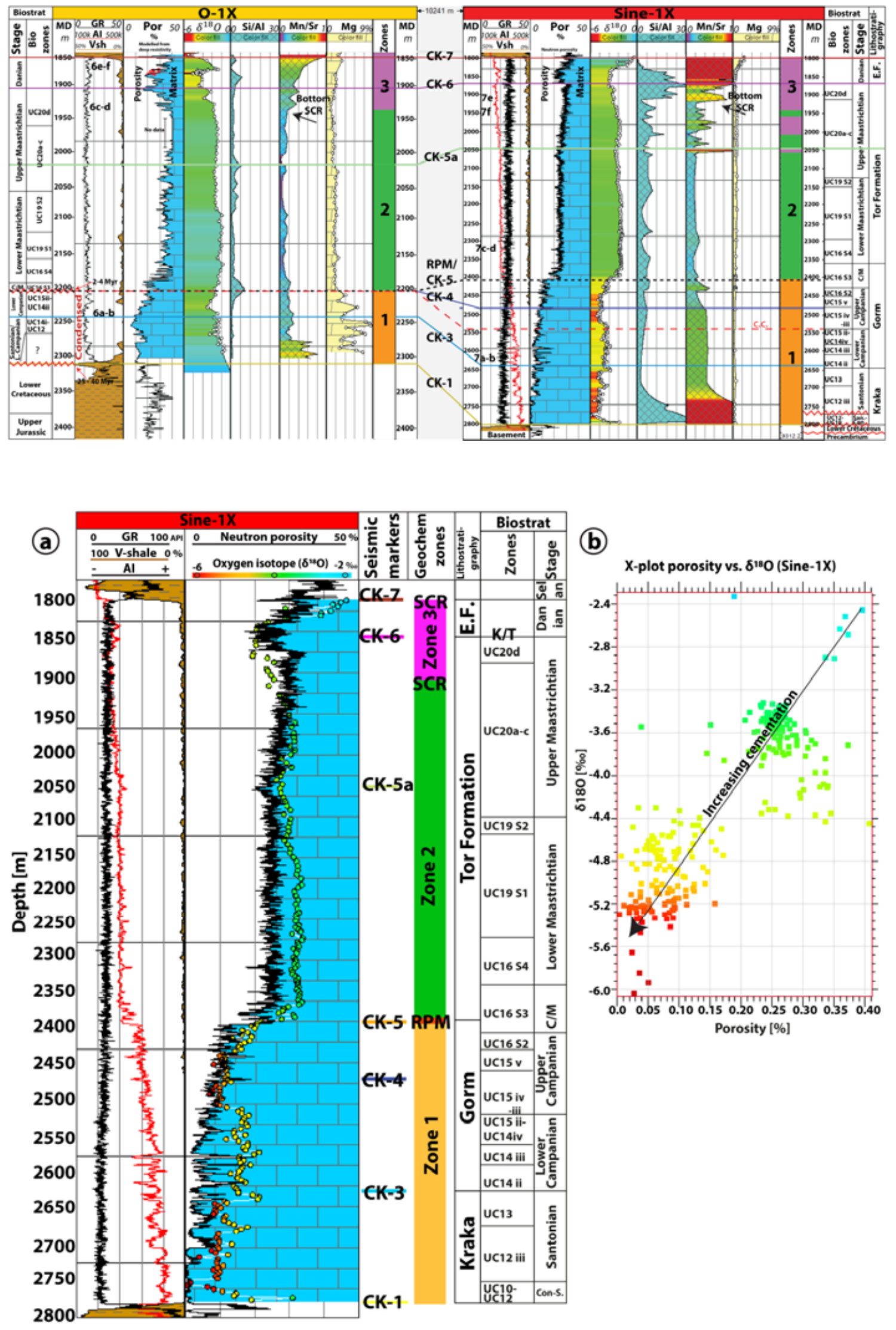

This article is protected by copyright. All rights reserved. 


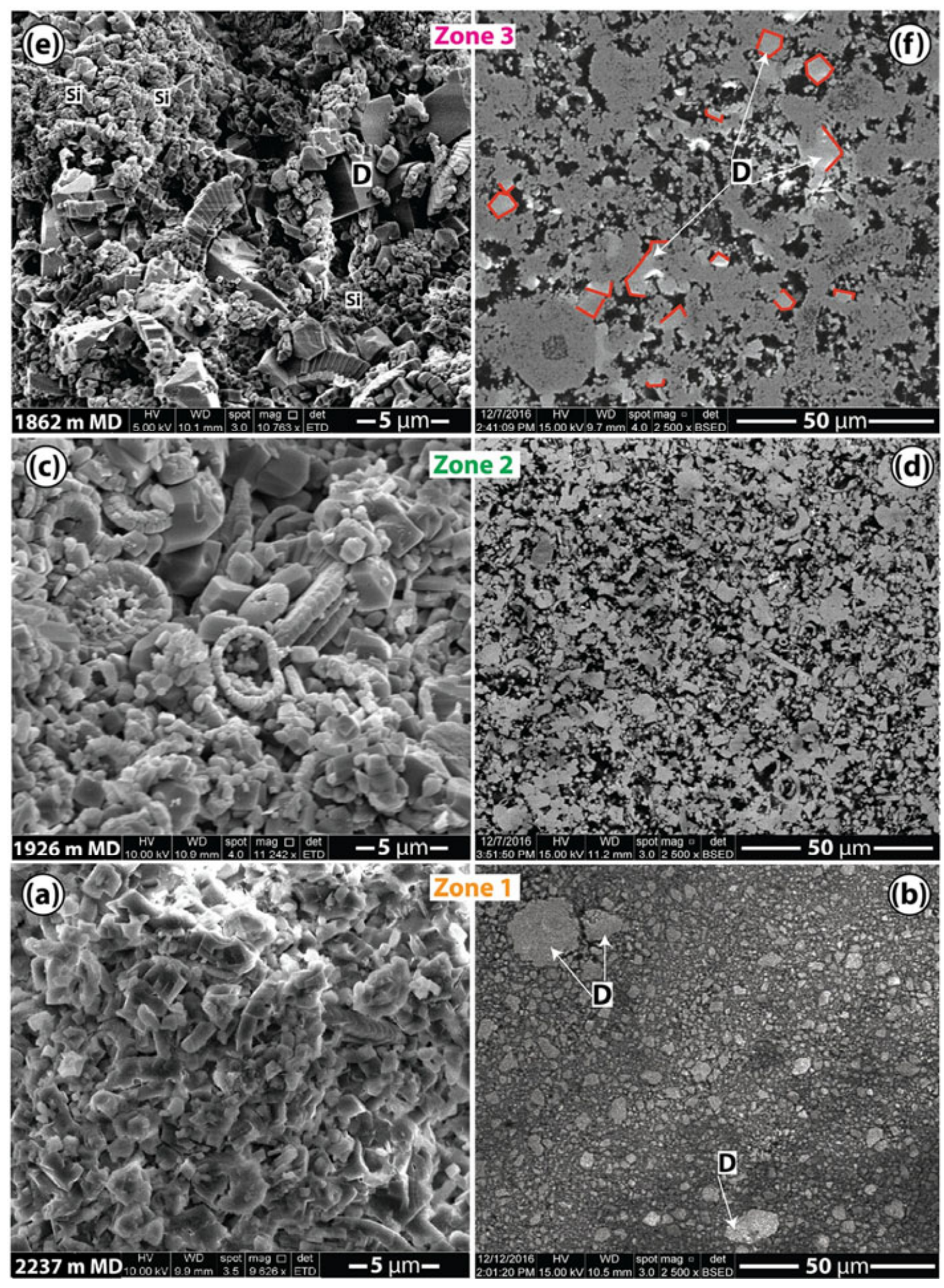

This article is protected by copyright. All rights reserved. 

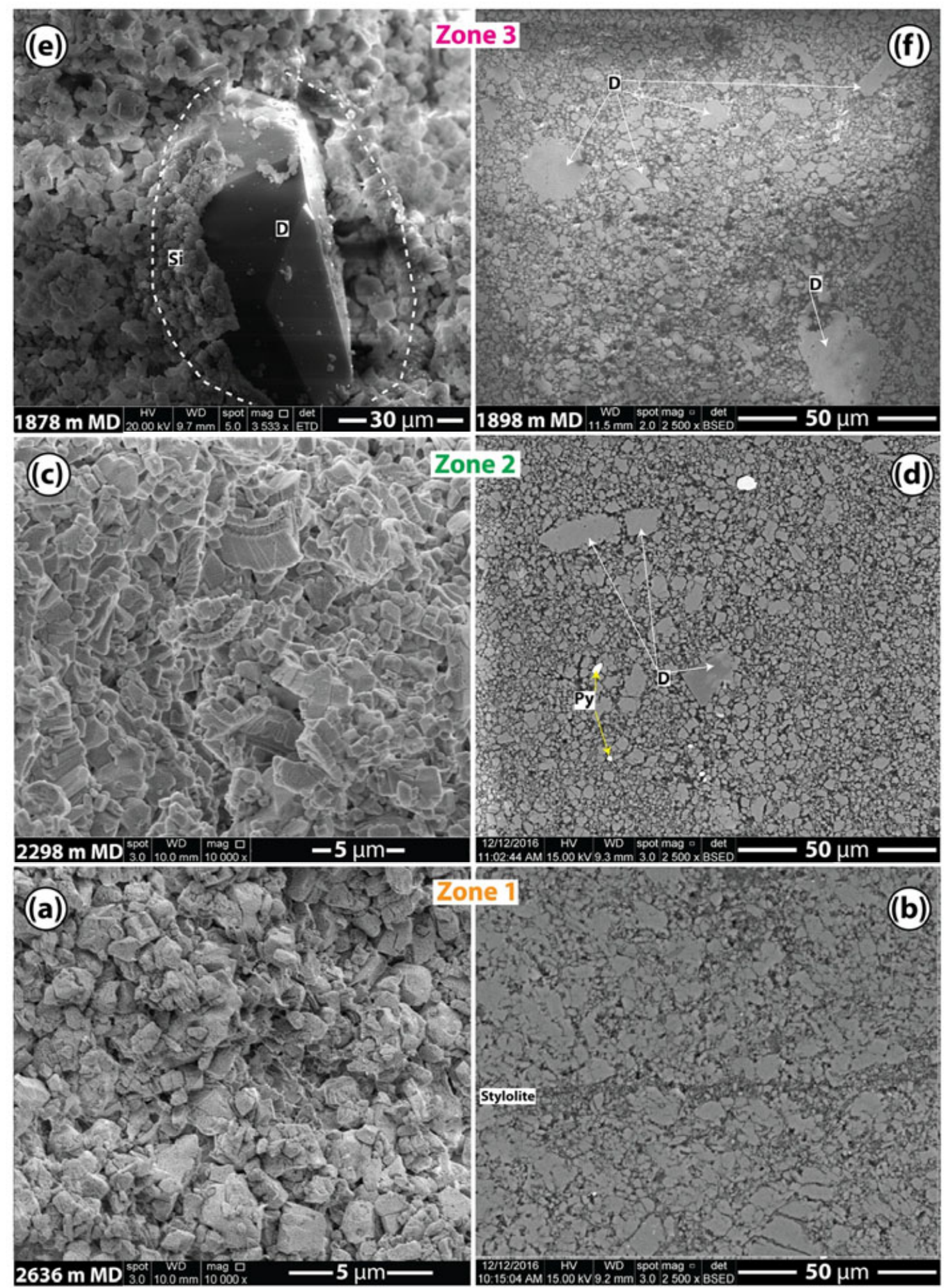

This article is protected by copyright. All rights reserved. 

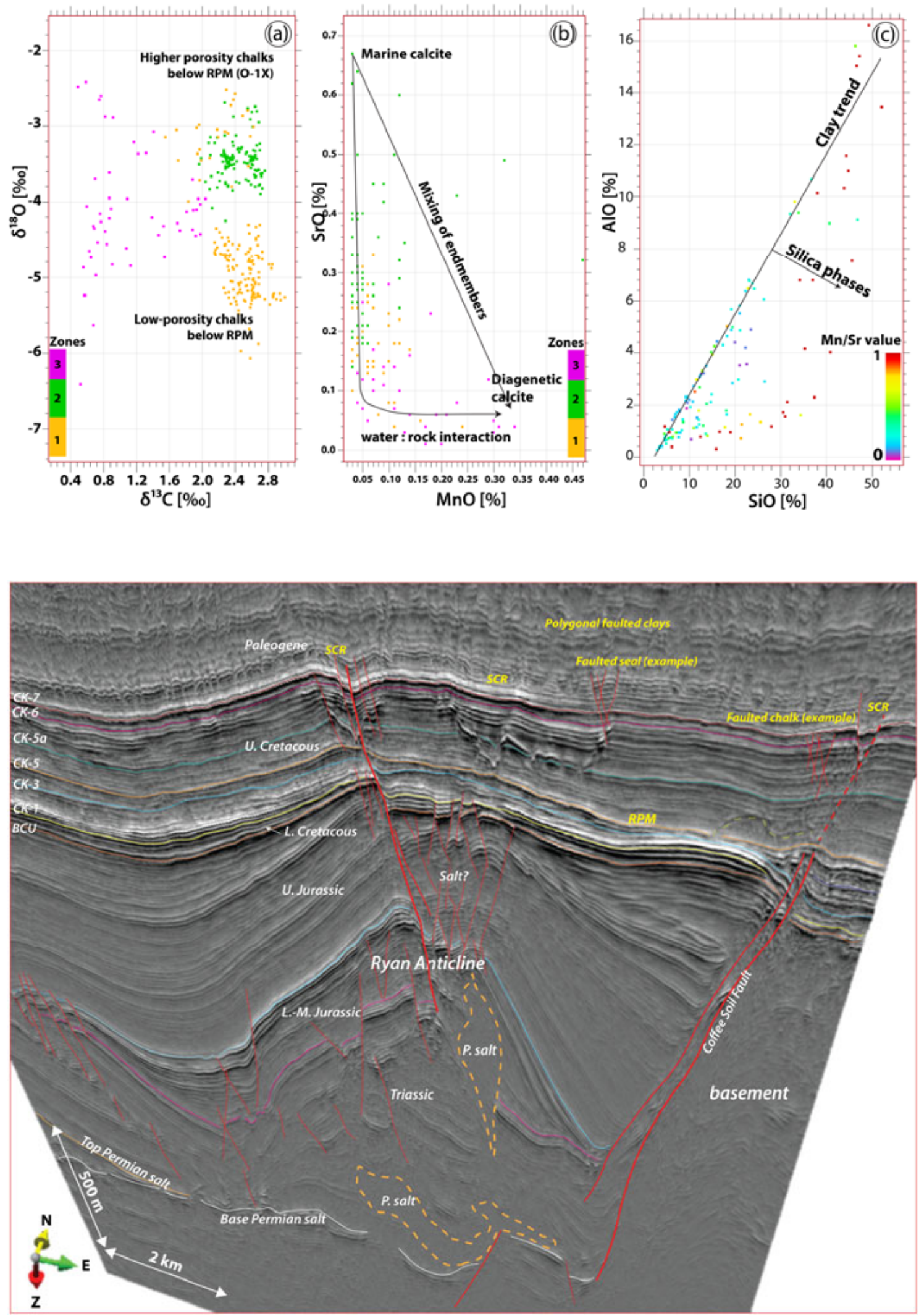

This article is protected by copyright. All rights reserved. 

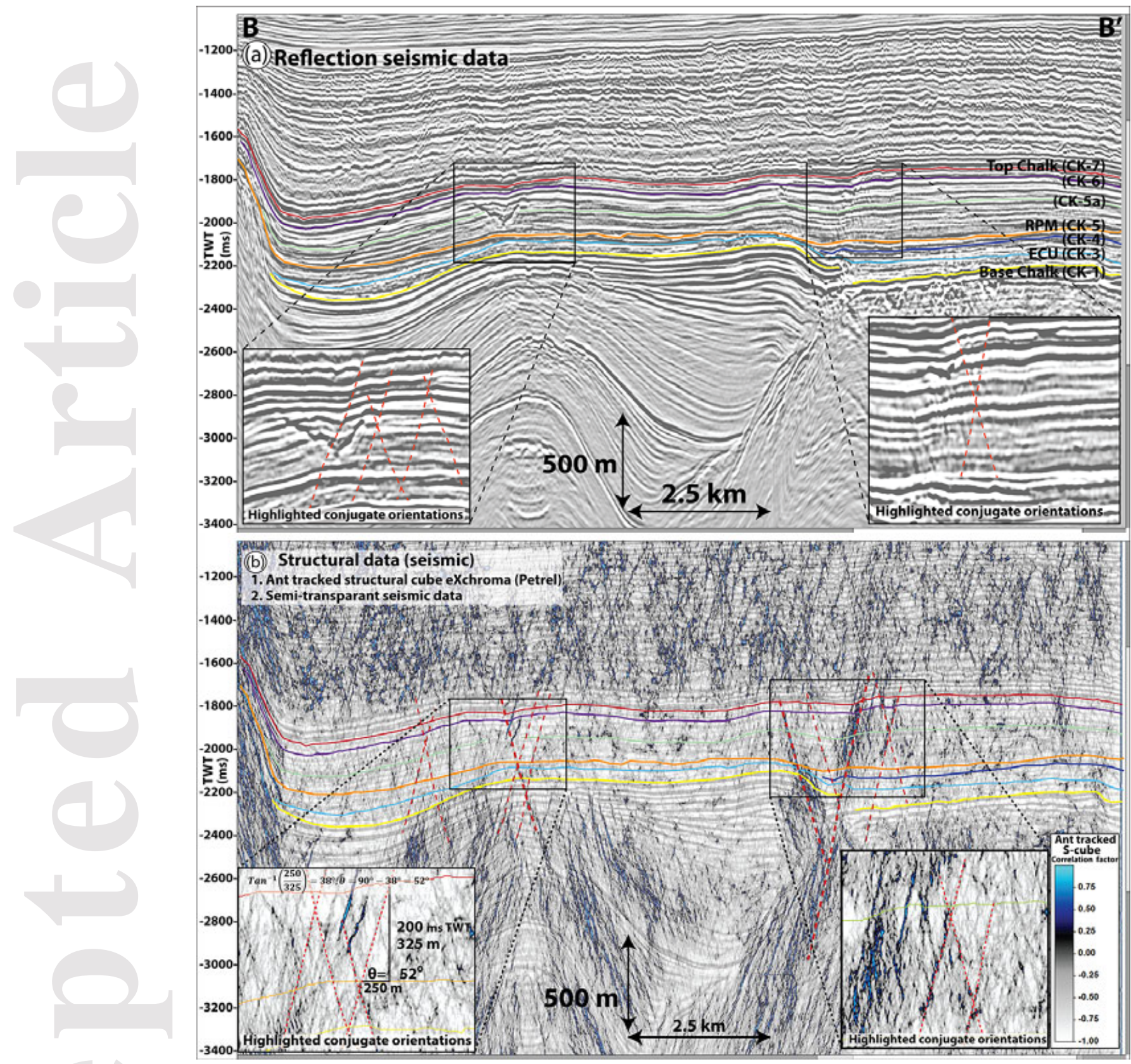

This article is protected by copyright. All rights reserved. 


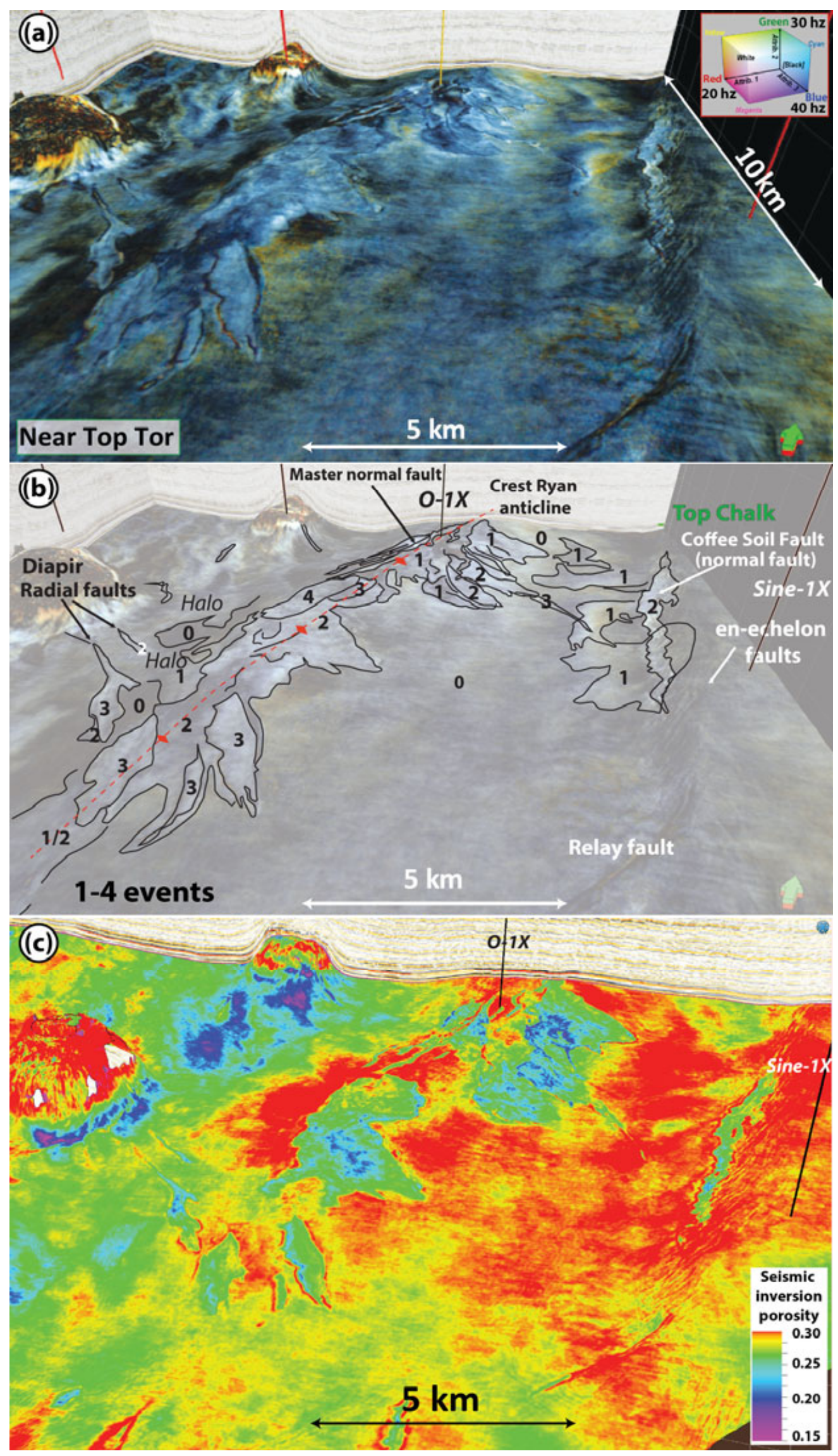

This article is protected by copyright. All rights reserved. 

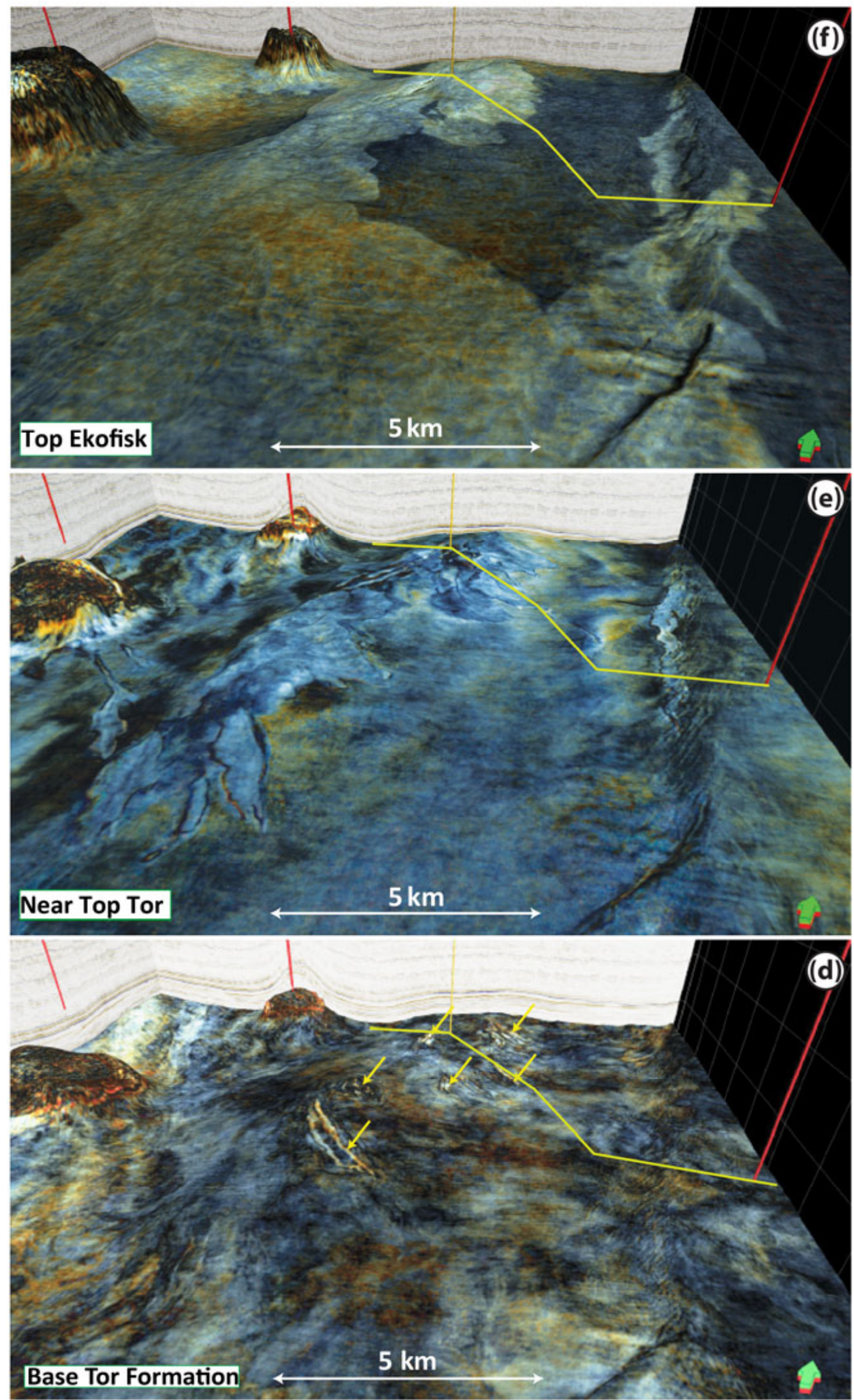

This article is protected by copyright. All rights reserved. 


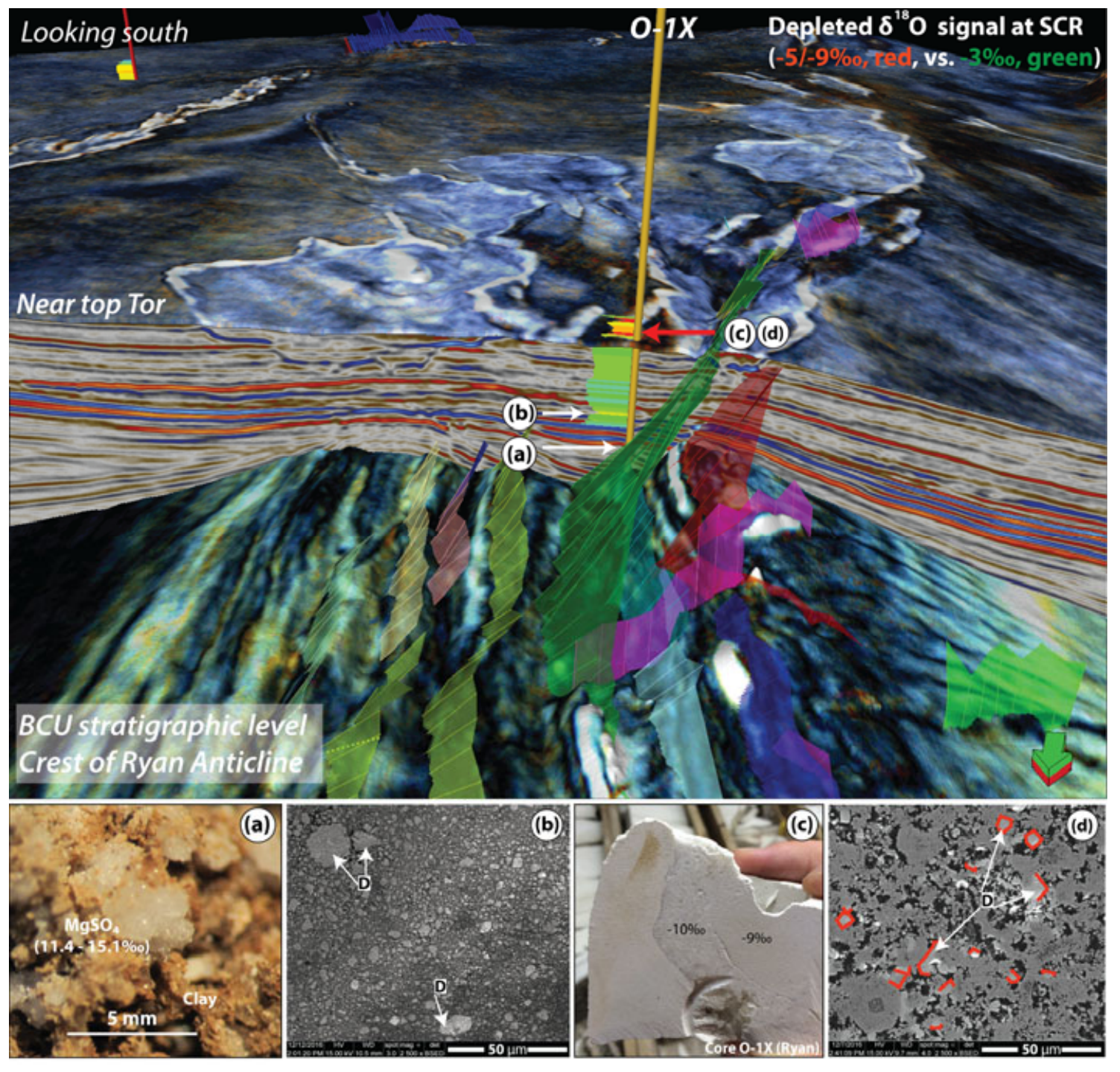

This article is protected by copyright. All rights reserved. 


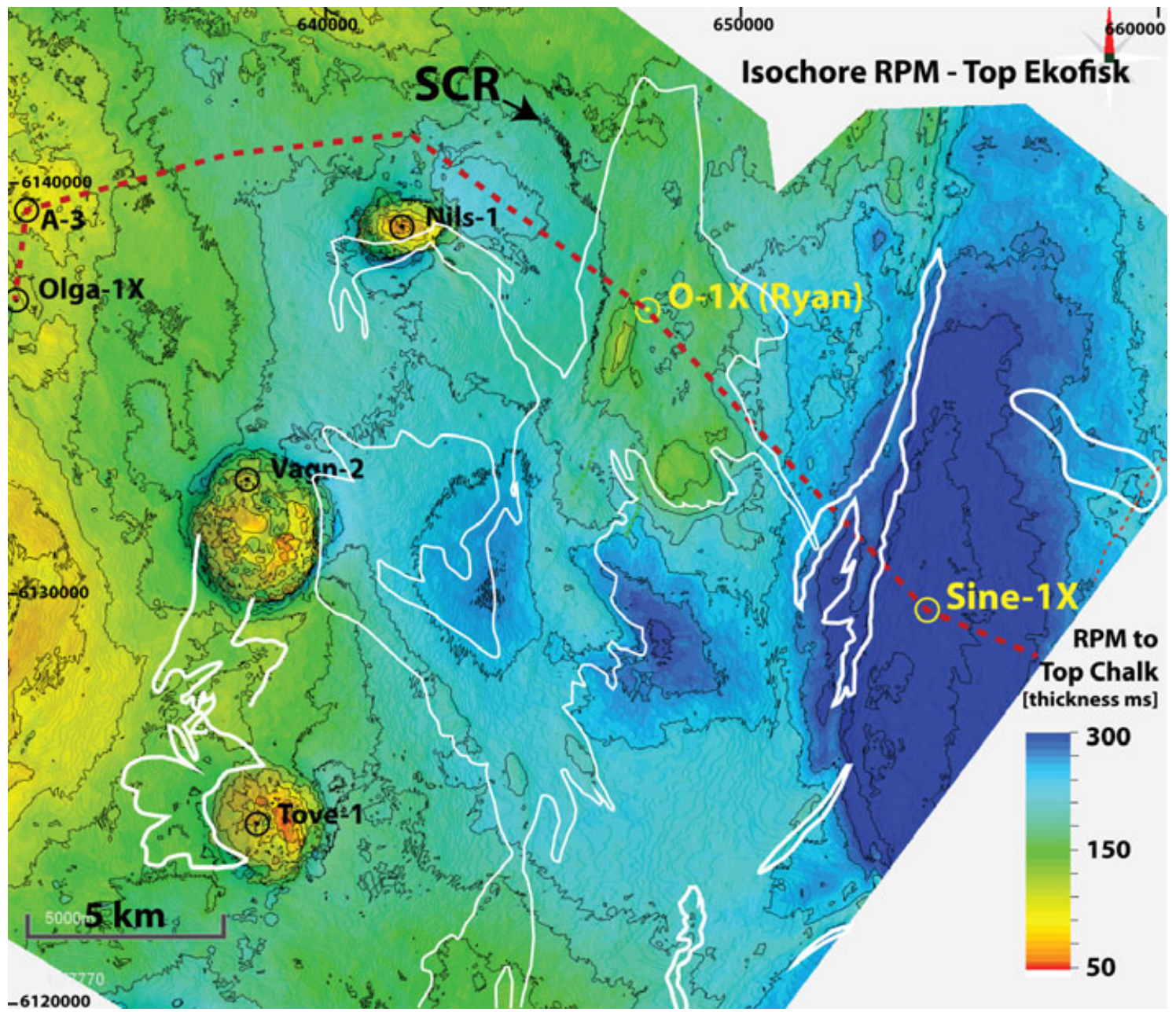

This article is protected by copyright. All rights reserved. 

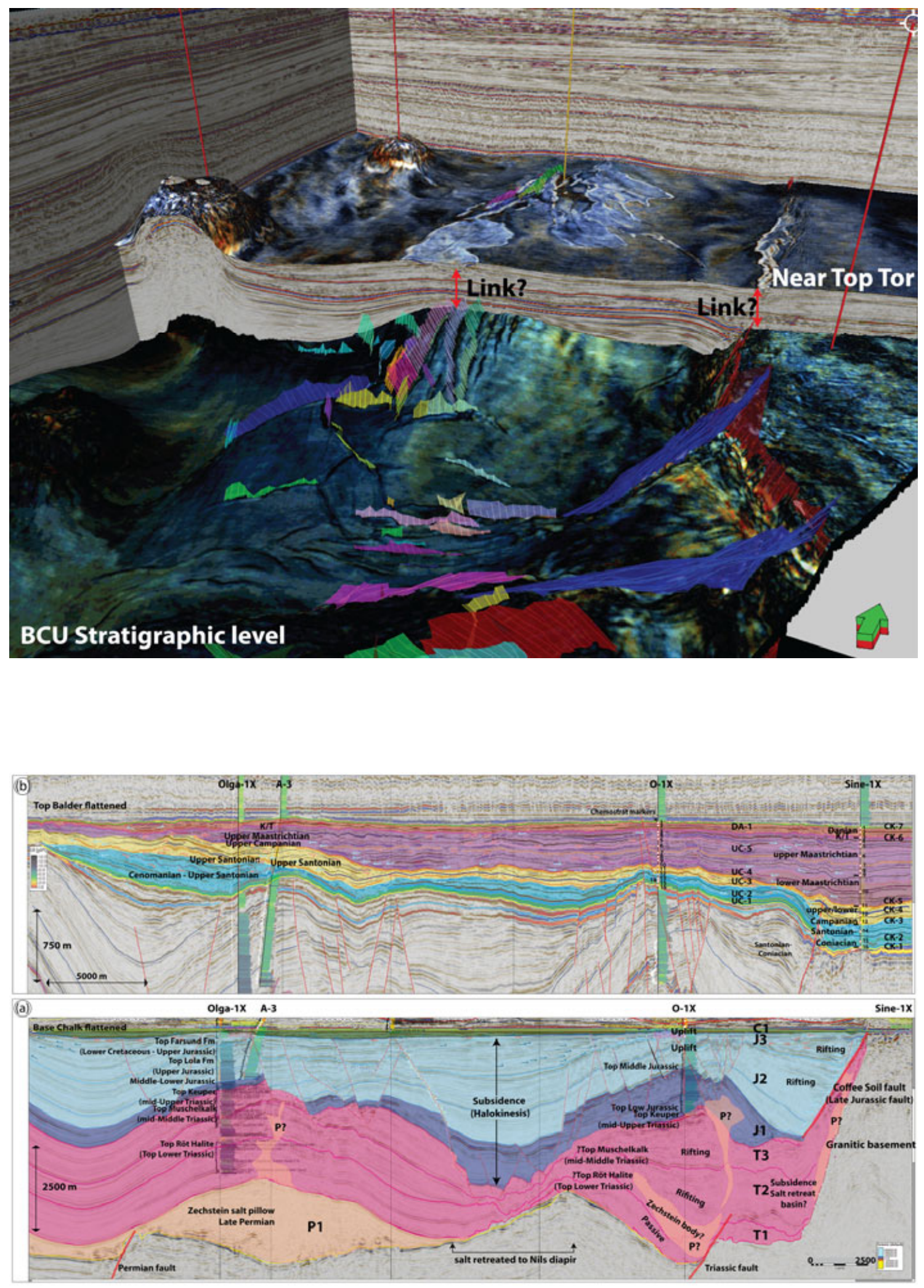

This article is protected by copyright. All rights reserved. 

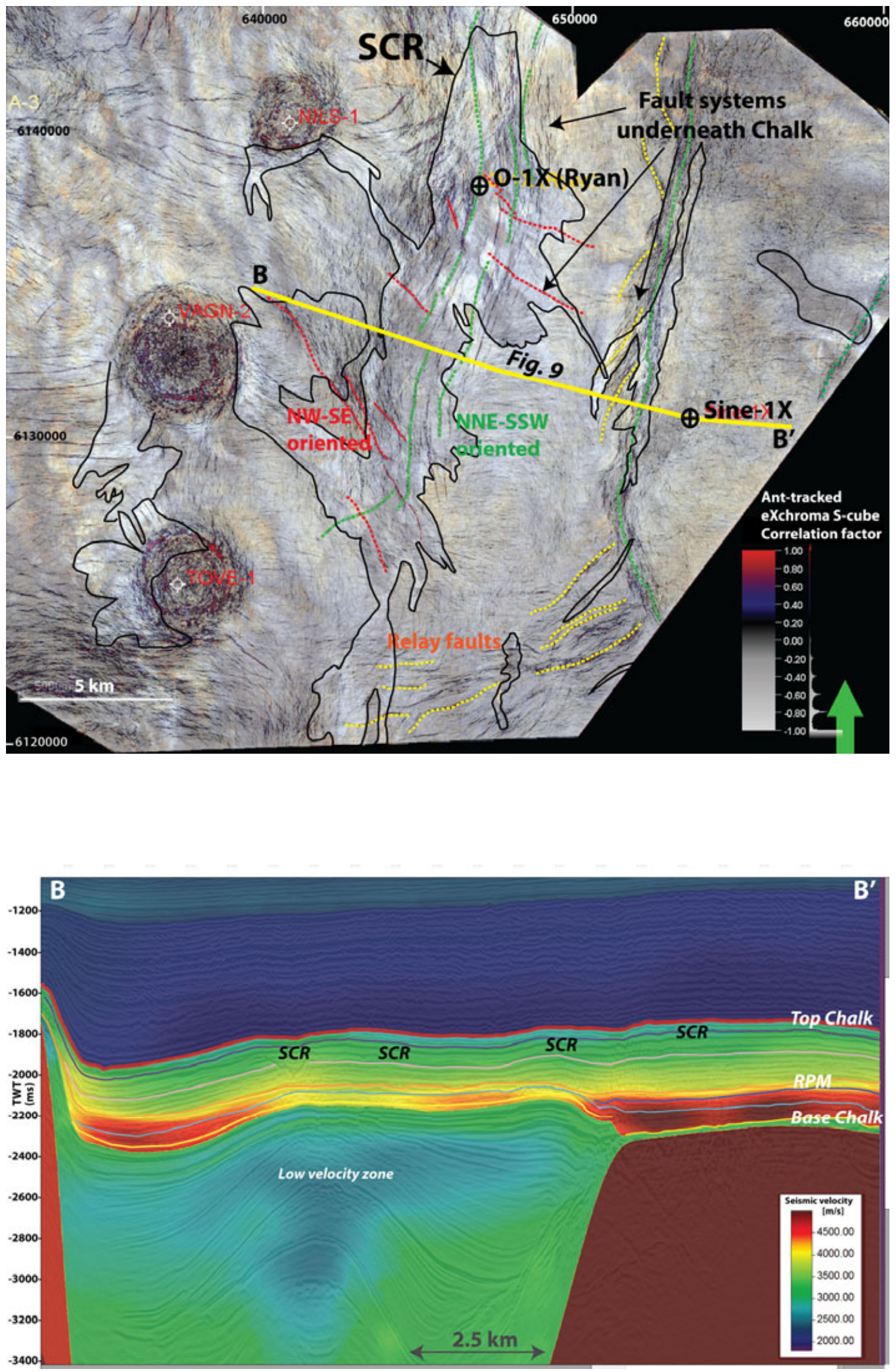

This article is protected by copyright. All rights reserved. 

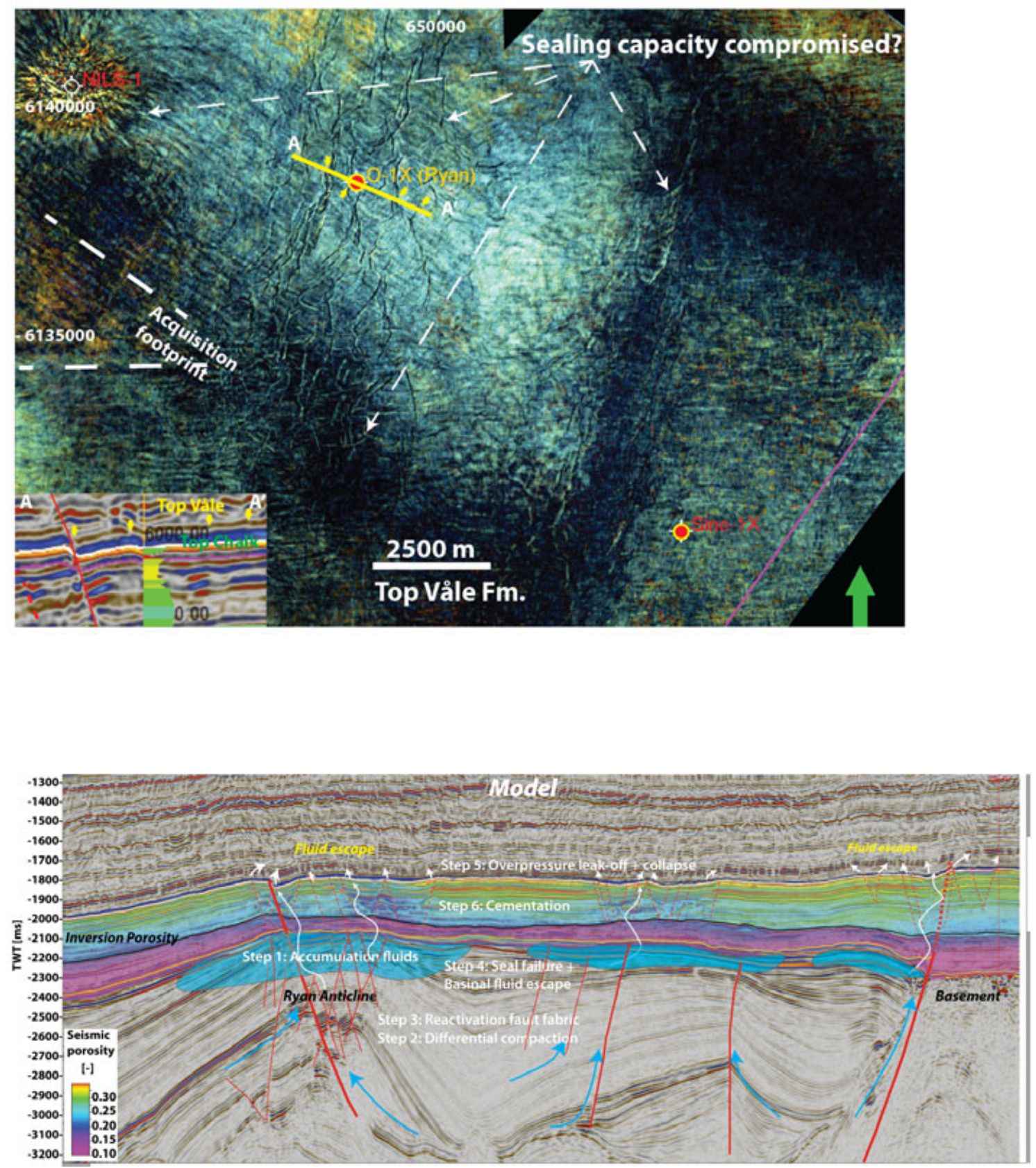

This article is protected by copyright. All rights reserved. 